\title{
Development of Sulfide Solid Electrolytes and Interface Formation Processes for Bulk-Type All-Solid- State Li and $\mathrm{Na}$ Batteries
}

\author{
Akitoshi Hayashi ${ }^{1 *}$, Atsushi Sakuda ${ }^{1,2}$ and Masahiro Tatsumisago ${ }^{1}$ \\ ${ }^{1}$ Department of Applied Chemistry, Graduate School of Engineering, Osaka Prefecture University, Sakai, Osaka, Japan, \\ ${ }^{2}$ Department of Energy and Environment, Research Institute of Electrochemical Energy, National Institute of Advanced \\ Industrial Science and Technology (AIST), Ikeda, Osaka, Japan
}

OPEN ACCESS

Edited by:

Shyue Ping Ong, University of California,

San Diego, USA

Reviewed by:

Liqiang Mai,

Wuhan University of

Technology, China

Xiao-Liang Wang,

Seeo Inc., USA

*Correspondence:

Akitoshi Hayashi

hayashi@chem.osakafu-u.ac.jp

Specialty section:

This article was submitted

to Energy Storage,

a section of the journal

Frontiers in Energy Research

Received: 01 March 2016

Accepted: 16 June 2016

Published: 15 July 2016

Citation:

Hayashi A, Sakuda A and

Tatsumisago M (2016) Development of Sulfide Solid Electrolytes and Interface Formation Processes

for Bulk-Type All-Solid-State $\mathrm{Li}$ and Na Batteries.

Front. Energy Res. 4:25.

doi: 10.3389/fenrg.2016.00025
All-solid-state batteries with inorganic solid electrolytes (SEs) are recognized as an ultimate goal of rechargeable batteries because of their high safety, versatile geometry, and good cycle life. Compared with thin-film batteries, increasing the reversible capacity of bulk-type all-solid-state batteries using electrode active material particles is difficult because contact areas at solid-solid interfaces between the electrode and electrolyte particles are limited. Sulfide SEs have several advantages of high conductivity, wide electrochemical window, and appropriate mechanical properties, such as formability, processability, and elastic modulus. Sulfide electrolyte with $\mathrm{Li}_{7} \mathrm{P}_{3} \mathrm{~S}_{11}$ crystal has a high $\mathrm{Li}^{+}$ ion conductivity of $1.7 \times 10^{-2} \mathrm{~S} \mathrm{~cm}^{-1}$ at $25^{\circ} \mathrm{C}$. It is far beyond the $\mathrm{Li}^{+}$ion conductivity of conventional organic liquid electrolytes. The $\mathrm{Na}^{+}$ion conductivity of $7.4 \times 10^{-4} \mathrm{~S} \mathrm{~cm}^{-1}$ is achieved for $\mathrm{Na}_{3.06} \mathrm{P}_{0.94} \mathrm{Si}_{0.06} \mathrm{~S}_{4}$ with cubic structure. Moreover, formation of favorable solid-solid interfaces between electrode and electrolyte is important for realizing solid-state batteries. Sulfide electrolytes have better formability than oxide electrolytes. Consequently, a dense electrolyte separator and closely attached interfaces with active material particles are achieved via "room-temperature sintering" of sulfides merely by cold pressing without heat treatment. Elastic moduli for sulfide electrolytes are smaller than that of oxide electrolytes, and $\mathrm{Na}_{2} \mathrm{~S}_{-} \mathrm{P}_{2} \mathrm{~S}_{5}$ glass electrolytes have smaller Young's modulus than $\mathrm{Li}_{2} \mathrm{~S}-\mathrm{P}_{2} \mathrm{~S}_{5}$ electrolytes. Cross-sectional SEM observations for a positive electrode layer reveal that sulfide electrolyte coating on active material particles increases interface areas even with a minimum volume of electrolyte, indicating that the energy density of bulk-type solid-state batteries is enhanced. Both surface coating of electrode particles and preparation of nanocomposite are effective for increasing the reversible capacity of the batteries. Our approaches to form solid-solid interfaces are demonstrated.

Keywords: all-solid-state battery, lithium battery, sodium battery, sulfide, solid electrolyte, electrode-electrolyte interface 


\section{INTRODUCTION}

All-solid-state batteries using inorganic solid electrolytes (SEs), used in place of conventional organic liquid electrolytes, have been studied because of their high safety (non-flammability with no liquid leakage), long cycle life, and versatile geometries (Takada, 2013; Tatsumisago et al., 2013; Tatsumisago and Hayashi, 2014). These features are important for large rechargeable lithium batteries with high energy density for application to eco-cars, such as electric vehicles and plug-in hybrid vehicles. Rechargeable sodium batteries are also attractive for large-scale applications for stationary load-leveling because sodium is expected to be the next targeted element after lithium based on its atomic weight, standard potential, and natural abundance (Yabuchi et al., 2015b; Yamada, 2014).

A key material to realize all-solid-state rechargeable batteries is a superior SE. In lithium ion conductors, sulfide electrolytes of $\mathrm{Li}_{10} \mathrm{GeP}_{2} \mathrm{~S}_{12}$ and $\mathrm{Li}_{7} \mathrm{P}_{3} \mathrm{~S}_{11}$ have high room-temperature conductivity of more than $10^{-2} \mathrm{~S} \mathrm{~cm}^{-1}$, which is as high as the conductivity of conventional organic liquid electrolytes (Kamaya et al., 2011; Seino et al., 2014). The lithium ion transport number of liquid electrolytes is below 0.5 , whereas that of SE is 1 . It is noteworthy that the conductivity of lithium ions of sulfide SEs already exceeds that of organic liquid electrolytes. Very recently, $\mathrm{Li}_{9.54} \mathrm{Si}_{1.74} \mathrm{P}_{1.44} \mathrm{~S}_{11.7} \mathrm{Cl}_{0.3}$ has been reported to show the highest conductivity of $2.5 \times 10^{-2} \mathrm{~S} \mathrm{~cm}^{-1}$. Using this superior electrolyte, high power competing with that of supercapacitors can be achieved in all-solid-state rechargeable lithium batteries (Kato et al., 2016b). Sulfide SEs have several important benefits of high conductivity, wide electrochemical window, and appropriate mechanical properties, such as formability and elastic modulus. A shortcoming of sulfide electrolytes is its low air stability. To realize bulk-type all-solid-state batteries, the formation of favorable solid-solid interfaces between electrode and electrolyte is important in addition to the development of superior sulfide electrolytes. Direct coating of sulfide electrolytes on active material particles instead of adding electrolyte particle is effective for forming a close solidsolid interface with large contact area. Insulative active materials, such as sulfur and $\mathrm{Li}_{2} \mathrm{~S}$, should be blended not only with SE but also with carbon-conductive additive to form ion and electron conduction paths to active materials. Nanocomposites of the three components are useful by preparation with high-energy ball milling, which pulverizes and combines them. Transition metal sulfides $\left(\mathrm{MS}_{x}\right)$ with high conductivity have good compatibility with sulfide SEs having the same sulfide anions. Especially, sulfurrich compounds, such as $\mathrm{TiS}_{3}$, are attractive active materials with high reversible capacity. Lithium metal is a supremely negative electrode, but issues related to lithium dendrites prevent its commercialization. Combination with a SE is a promising solution. Interface modification between Li metal and the SE is important.

As described in this paper, the recent development of sulfide SEs and interface formation processes for bulk-type all-solid-state $\mathrm{Li}$ and Na batteries are reviewed. Significant properties as SEs of conductivity, chemical stability, and mechanical property for $\mathrm{Li}^{+}$ or $\mathrm{Na}^{+}$ion conducting sulfides are reported. Procedures for preparing sulfide electrolytes, such as mechanical milling and liquidphase synthesis, are also described. Several approaches to form favorable solid-solid interfaces developed by our research group are demonstrated. Processes for the coating of sulfide electrolytes via gas-phase or liquid-phase process on $\mathrm{LiCoO}_{2}$ or graphite particles have been developed. Preparation of nanocomposite electrodes with sulfur, $\mathrm{Li}_{2} \mathrm{~S}$, and $\mathrm{Li}_{3} \mathrm{PS}_{4}$ (as a bifunctional material of electrolyte and electrode) particles is described, along with the use of $\mathrm{MS}_{x}$ active materials. Formation of a solid-solid interface for using lithium metal negative electrodes is also discussed.

\section{DEVELOPMENT OF SULFIDE SOLID ELECTROLYTES}

Sulfide SEs with $\mathrm{Li}^{+}$or $\mathrm{Na}^{+}$ion conductivity have been developed during the past three decades. Recently, chemical stability and mechanical properties as well as conductivity for sulfide electrolytes have attracted much attention. Sulfide electrolytes are prepared using several techniques with solid-phase reaction, melt-quenching, mechanical milling, crystallization of mother glasses, and liquid-phase reaction. Detailed information related to electrolyte properties will be presented in the following sections of this report.

\section{Conductivity}

Inorganic sulfide SEs with high $\mathrm{Li}^{+}$or $\mathrm{Na}^{+}$ion conductivities have been developed. Sulfide electrolytes with high conductivities are presented in Table 1. In $\mathrm{Li}^{+}$ion conducting sulfide electrolytes, crystalline $\mathrm{Li}_{10} \mathrm{GeP}_{2} \mathrm{~S}_{12}$ (LGPS; Kamaya et al., 2011) and glassceramic $\mathrm{Li}_{7} \mathrm{P}_{3} \mathrm{~S}_{11}$ (Seino et al., 2014) have considerably high conductivity of more than $10^{-2} \mathrm{~S} \mathrm{~cm}^{-1}$ at $25^{\circ} \mathrm{C}$, which is beyond the $\mathrm{Li}^{+}$ion conductivity of conventional organic liquid electrolytes. Very recently, $\mathrm{Li}_{9.54} \mathrm{Si}_{1.74} \mathrm{P}_{1.44} \mathrm{~S}_{11.7} \mathrm{Cl}_{0.3}$ with LGPS structure has been reported to show the highest conductivity of $2.5 \times 10^{-2} \mathrm{~S} \mathrm{~cm}^{-1}$ (Kato et al., 2016b). Studies investigating new electrolytes with much higher conductivity are in progress. Several crystals, such as $\mathrm{Li}_{10} \mathrm{SnP}_{2} \mathrm{~S}_{12}$ (Boron et al., 2013) and $\mathrm{Li}_{6} \mathrm{PS}_{5} \mathrm{Cl}$ (Boulineau et al., 2012), have high conductivity of more than $10^{-3} \mathrm{~S} \mathrm{~cm}^{-1}$. This conductivity is also achieved by the addition of lithium halides to sulfide glass and glass-ceramic electrolytes (Wada et al., 1983; Ujiie et al., 2014).

The $\mathrm{Na}^{+}$ion conductivity is lower than $\mathrm{Li}^{+}$ion conductivity in glassy electrolytes. Ionic conduction of $\mathrm{Na}^{+}$ion with ionic radius larger than $\mathrm{Li}^{+}$ion is unfavorable in glasses (Souquet et al., 1981). For sodium ion conductors, sulfides with high conductivity had not been found since this report described $\mathrm{Na}_{3} \mathrm{PS}_{4}$ glass-ceramic electrolytes in 2012. A cubic $\mathrm{Na}_{3} \mathrm{PS}_{4}$ phase is precipitated by crystallization of a mother $\mathrm{Na}_{3} \mathrm{PS}_{4}$ glass. The prepared glass-ceramic electrolyte shows $\mathrm{Na}^{+}$ion conductivity of greater than $10^{-4} \mathrm{~S} \mathrm{~cm}^{-1}$ at $25^{\circ} \mathrm{C}$ (Hayashi et al., 2012b). Furthermore, partial substitution of Si for $\mathrm{P}_{\text {in }} \mathrm{Na}_{3} \mathrm{PS}_{4}$ is useful for increasing conductivity (Tanibata et al., 2014). Figure 1 presents the composition dependence of conductivities at $25^{\circ} \mathrm{C}$ for $\mathrm{Na}_{3} \mathrm{PS}_{4}-\mathrm{Na}_{4} \mathrm{SiS}_{4}$ glass-ceramic electrolytes. The replacement of $6 \mathrm{~mol} \% \mathrm{Na}_{3} \mathrm{PS}_{4}$ by $\mathrm{Na}_{4} \mathrm{SiS}_{4}$ increases the conductivity from $4.6 \times 10^{-4}$ to $7.4 \times 10^{-4} \mathrm{~S} \mathrm{~cm}^{-1}$. The electron density distribution of the cubic $\mathrm{Na}_{3} \mathrm{PS}_{4}$ structure obtained using the maximum entropy method is shown in the inset of Figure 1. $\mathrm{Na}_{3} \mathrm{PS}_{4}$ has three-dimensional 
TABLE 1 | $\mathrm{Li}^{+}$ion and $\mathrm{Na}^{+}$ion conductivities for sulfide solid electrolytes.

\begin{tabular}{|c|c|c|c|}
\hline Composition & $\begin{array}{l}\text { Conductivity } \\
\text { at } 25^{\circ} \mathrm{C}\left(\mathrm{S} \mathrm{cm}^{-1}\right)\end{array}$ & Classification & Reference \\
\hline $\mathrm{Li}_{9.54} \mathrm{Si}_{1.74} \mathrm{P}_{1.44} \mathrm{~S}_{11.7} \mathrm{Cl}_{0.3}$ & $2.5 \times 10^{-2}$ & Crystal & $\begin{array}{l}\text { (Kato et al. } \\
2016 b)\end{array}$ \\
\hline $\mathrm{Li}_{10} \mathrm{GeP}_{2} \mathrm{~S}_{12}$ & $1.2 \times 10^{-2}$ & Crystal & $\begin{array}{l}\text { Kamaya et al. } \\
(2011)\end{array}$ \\
\hline $\mathrm{Li}_{10} \mathrm{SnP}_{2} \mathrm{~S}_{12}$ & $4 \times 10^{-3}$ & Crystal & $\begin{array}{l}\text { Boron et al. } \\
(2013)\end{array}$ \\
\hline $\mathrm{Li}_{3.833} \mathrm{Sn}_{0.833} \mathrm{As}_{0.166} \mathrm{~S}_{4}$ & $1.4 \times 10^{-3}$ & Crystal & $\begin{array}{l}\text { Sahu et al. } \\
(2014)\end{array}$ \\
\hline $\mathrm{Li}_{6} \mathrm{PS}_{5} \mathrm{Cl}$ & $1.3 \times 10^{-3}$ & Crystal & $\begin{array}{l}\text { Boulineau et al. } \\
(2012)\end{array}$ \\
\hline $70 \mathrm{Li}_{2} \mathrm{~S} \cdot 30 \mathrm{P}_{2} \mathrm{~S}_{5}\left(\mathrm{Li}_{7} \mathrm{P}_{3} \mathrm{~S}_{11}\right)$ & $1.7 \times 10^{-2}$ & Glass-ceramic & $\begin{array}{l}\text { Seino et al. } \\
(2014)\end{array}$ \\
\hline $63 \mathrm{Li}_{2} \mathrm{~S} \cdot 27 \mathrm{P}_{2} \mathrm{~S}_{5} \cdot 10 \mathrm{LiBr}$ & $8.4 \times 10^{-3}$ & Glass-ceramic & Ujiie et al. (2014) \\
\hline $80 \mathrm{Li}_{2} \mathrm{~S} \cdot 2 \mathrm{OP}_{2} \mathrm{~S}_{5}$ & $1.3 \times 10^{-3}$ & Glass-ceramic & $\begin{array}{l}\text { Mizuno et al. } \\
(2006)\end{array}$ \\
\hline $30 \mathrm{Li}_{2} \mathrm{~S} \cdot 26 \mathrm{~B}_{2} \mathrm{~S}_{3} \cdot 44 \mathrm{Lil}$ & $1.7 \times 10^{-3}$ & Glass & $\begin{array}{l}\text { Wada et al. } \\
(1983)\end{array}$ \\
\hline $50 \mathrm{Li}_{2} \mathrm{~S} \cdot 17 \mathrm{P}_{2} \mathrm{~S}_{5} \cdot 33 \mathrm{LiBH}_{4}$ & $1.6 \times 10^{-3}$ & Glass & $\begin{array}{l}\text { Yamauchi et al. } \\
(2013)\end{array}$ \\
\hline $63 \mathrm{Li}_{2} \mathrm{~S} \cdot 36 \mathrm{SiS}_{2} \cdot 1 \mathrm{Li}_{3} \mathrm{PO}_{4}$ & $1.5 \times 10^{-3}$ & Glass & $\begin{array}{l}\text { Aotani et al. } \\
(1994)\end{array}$ \\
\hline $70 \mathrm{Li}_{2} \mathrm{~S} \cdot 30 \mathrm{P}_{2} \mathrm{~S}_{5}$ & $1.6 \times 10^{-4}$ & Glass & $\begin{array}{l}\text { Zhang and } \\
\text { Kennedy (1990) }\end{array}$ \\
\hline $\mathrm{Na}_{3} \mathrm{PSe}_{4}$ & $1.2 \times 10^{-3}$ & Crystal & $\begin{array}{l}\text { Zhang et al. } \\
(2015)\end{array}$ \\
\hline $\mathrm{Na}_{3} \mathrm{PS}_{4}$ (tetragonal) & $1 \times 10^{-6}$ & Crystal & $\begin{array}{l}\text { Jansen and } \\
\text { Henseler (1992) }\end{array}$ \\
\hline $94 \mathrm{Na}_{3} \mathrm{PS}_{4} \cdot 6 \mathrm{Na}_{4} \mathrm{SiS}_{4}$ & $7.4 \times 10^{-4}$ & Glass-ceramic & $\begin{array}{l}\text { Tanibata et al. } \\
\text { (2014) }\end{array}$ \\
\hline $\mathrm{Na}_{3} \mathrm{PS}_{4}$ (cubic) & $2 \times 10^{-4}$ & Glass-ceramic & $\begin{array}{l}\text { Hayashi et al., } \\
(2012 b)\end{array}$ \\
\hline $60 \mathrm{Na}_{2} \mathrm{~S} \cdot 40 \mathrm{GeS}_{2}$ & $7.3 \times 10^{-6}$ & Glass & $\begin{array}{l}\text { Souquet et al. } \\
\text { (1981) }\end{array}$ \\
\hline
\end{tabular}

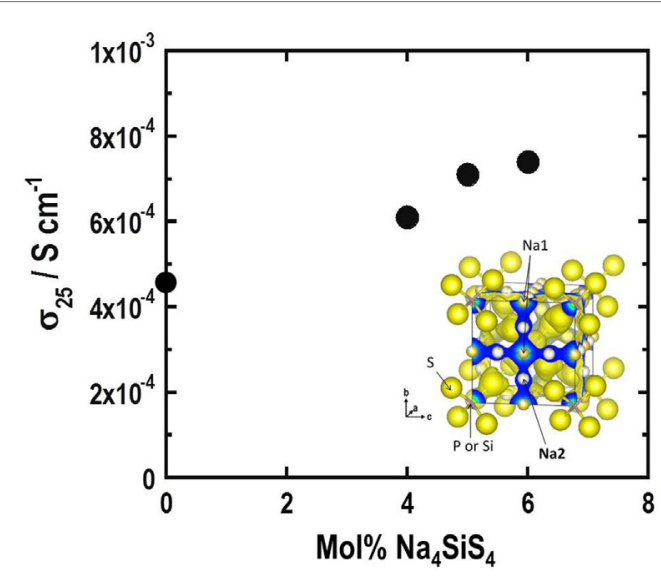

FIGURE 1 | Composition dependence of conductivity at $25^{\circ} \mathrm{C}$ for $(100-x) \mathrm{Na}_{3} \mathrm{PS}_{4} \cdot x \mathrm{Na}_{4} \mathrm{SiS}_{4}(\mathrm{~mol} \%)$ glass-ceramic electrolytes. The inset shows the electron density distribution of the cubic $\mathrm{Na}_{3} \mathrm{PS}_{4}$ structure.

$\mathrm{Na}^{+}$ion conduction paths along $\mathrm{Na} 1$ and $\mathrm{Na} 2$ sites. Increased $\mathrm{Na}^{+}$ ion concentration is presumed as the reason for the enhancement of conductivity. Very recently, high conductivity of more than $10^{-3} \mathrm{~S} \mathrm{~cm}^{-1}$ has been reported in crystalline $\mathrm{Na}_{3} \mathrm{PSe}_{4}$ (Zhang et al.,
2015). However, studies of new sulfide $\mathrm{Na}^{+}$ion conductors are few. A first-principles calculation indicates that $\mathrm{Sn}$-doped cubic $\mathrm{Na}_{3} \mathrm{PS}_{4}$ is predicted to have a higher $\mathrm{Na}^{+}$ion conductivity of $10^{-2} \mathrm{~S} \mathrm{~cm}^{-1}$ (Zhu et al., 2015). Synthesis of SEs with a favorable structure for $\mathrm{Na}^{+}$ion conduction based on calculation results is important for finding new $\mathrm{Na}^{+}$ion conducting SEs.

\section{Chemical Stability}

A shortcoming of sulfide electrolytes is their lower chemical stability in air atmosphere. Sulfides tend to be decomposed by hydrolysis, generating harmful $\mathrm{H}_{2} \mathrm{~S}$. Suppression of hydrolysis of sulfides is an important task for developing sulfide electrolytes. Based on our early experiments, the selection of compositions in sulfide electrolytes gives moderate stability in air to sulfide electrolytes (Muramatsu et al., 2011). The chemical stability of sulfide glass electrolytes in the binary system $\mathrm{Li}_{2} \mathrm{~S}-\mathrm{P}_{2} \mathrm{~S}_{5}$ was examined by exposing them to air atmosphere. Amounts of generated $\mathrm{H}_{2} \mathrm{~S}$ from the sulfides depend on the composition of the glasses; $\mathrm{H}_{2} \mathrm{~S}$ generation is minimized at the composition $75 \mathrm{Li}_{2} \mathrm{~S} \cdot 25 \mathrm{P}_{2} \mathrm{~S}_{5}(\mathrm{~mol} \%)$. The glass comprises $\mathrm{Li}^{+}$and $\mathrm{PS}_{4}^{3-}$ ions. An isolated anion $\mathrm{PS}_{4}^{3-}$ without bridging sulfurs is useful for high tolerance for hydrolysis. $\mathrm{Li}_{3} \mathrm{PS}_{4}$-based $\mathrm{SEs}$ with both good chemical stability and high conductivity have been prepared by the combination of oxides $\left(\mathrm{Li}_{2} \mathrm{O}\right.$ or $\left.\mathrm{P}_{2} \mathrm{O}_{5}\right)$ and iodides ( $\mathrm{LiI}$ ) (Ohtomo et al., 2013a,b). The addition of metal oxides, such as $\mathrm{ZnO}$, which act as an absorbent for $\mathrm{H}_{2} \mathrm{~S}$, is also effective for decreasing $\mathrm{H}_{2} \mathrm{~S}$ (Hayashi et al., 2013). It is noteworthy that the use of a favorable $\mathrm{M}_{\mathrm{x}} \mathrm{O}_{\mathrm{y}}\left(\mathrm{M}_{\mathrm{x}} \mathrm{O}_{\mathrm{y}}: \mathrm{Fe}_{2} \mathrm{O}_{3}, \mathrm{ZnO}\right.$, and $\left.\mathrm{Bi}_{2} \mathrm{O}_{3}\right)$ with a larger negative Gibbs energy change $(\Delta G)$ for the reaction with $\mathrm{H}_{2} \mathrm{~S}$ is effective for improving the chemical stability of sulfide electrolytes. Another approach is the use of sulfide compositions based on the hard and soft acids and bases theory (HSAB; Sahu et al., 2014). Lithium tin thiophosphate, $\mathrm{Li}_{4} \mathrm{SnS}_{4}$, has better air stability than that of $\mathrm{Li}_{3} \mathrm{PS}_{4}$. Actually, as-substituted $\mathrm{Li}_{4} \mathrm{SnS}_{4}$ has good features of both high conductivity of $10^{-3} \mathrm{~S} \mathrm{~cm}^{-1}$ and high air stability.

The chemical stability of SEs tends to affect battery performance. The electrochemical performance of all-solid-state $\mathrm{C} / \mathrm{LiCoO}_{2}$ cells using $\mathrm{Li}_{3} \mathrm{PS}_{4}$ glass or $\mathrm{Li}_{7} \mathrm{P}_{3} \mathrm{~S}_{11}$ glass-ceramic as a $\mathrm{SE}$ is compared. The cell with $\mathrm{Li}_{3} \mathrm{PS}_{4}$ glass electrolytes exhibits better cycle performance, although $\mathrm{Li}_{3} \mathrm{PS}_{4}$ glass has lower conductivity than $\mathrm{Li}_{7} \mathrm{P}_{3} \mathrm{~S}_{11}$ electrolyte (Ohtomo et al., 2013c). High performance of the battery would be based on the higher chemical stability of $\mathrm{Li}_{3} \mathrm{PS}_{4}$ electrolytes. Chemical stability as well as conductivity is an important factor of SEs for developing superior solid-state batteries.

\section{Mechanical Property}

Adhesion of the solid-solid interface is a key to the utilization of electrode active materials in all-solid-state batteries. Formability or processability of SEs is examined by the molding pressure dependence of the relative density of compressed powder pellets.

Figure $2 \mathrm{~A}$ shows the dependence of the relative density of $75 \mathrm{Li}_{2} \mathrm{~S} \cdot 25 \mathrm{P}_{2} \mathrm{~S}_{5}$ and $75 \mathrm{Na}_{2} \mathrm{~S} \cdot 25 \mathrm{P}_{2} \mathrm{~S}_{5}(\mathrm{~mol} \%)$ glass electrolytes on molding pressure. The relative densities increase gradually with an increase in molding pressure in both glasses at the same alkali compositions of $75 \mathrm{~mol} \% \mathrm{M}_{2} \mathrm{~S}(\mathrm{M}=\mathrm{Li}$ or $\mathrm{Na})$, whereas the relative density for the $\mathrm{Na}_{2} \mathrm{~S}$ system is higher than that for the $\mathrm{Li}_{2} \mathrm{~S}$ 
system (Sakuda et al., 2013a,b; Nose et al., 2015). Cross-sectional SEM images of the $75 \mathrm{~mol} \% \mathrm{M}_{2} \mathrm{~S}$ pellets pressed at $360 \mathrm{MPa}$ are shown in the inset. Grain boundaries and voids in the pellets are more decreased in the $75 \mathrm{Na}_{2} \mathrm{~S} \cdot 25 \mathrm{P}_{2} \mathrm{~S}_{5}$ glass compared with the $75 \mathrm{Li}_{2} \mathrm{~S} \cdot 25 \mathrm{P}_{2} \mathrm{~S}_{5}$ glass. Sulfide glasses are densified by cold pressing without heat treatment, and this densification phenomenon is called "room-temperature pressure sintering" (Sakuda et al., $2013 \mathrm{a}, \mathrm{b})$. It is noteworthy that the $75 \mathrm{Na}_{2} \mathrm{~S} \cdot 25 \mathrm{P}_{2} \mathrm{~S}_{5}$ glass has better formability than the $75 \mathrm{Li}_{2} \mathrm{~S} \cdot 25 \mathrm{P}_{2} \mathrm{~S}_{5}$ glass. Both the glasses comprise $\mathrm{Li}^{+}$or $\mathrm{Na}^{+}$ion and $\mathrm{PS}_{4}^{3-}$ ion, which are thought to diffuse at the particle boundaries on pressing at room temperature. $\mathrm{Na}^{+}$ ion with a larger ionic radius than $\mathrm{Li}^{+}$ion has a weaker interaction with $\mathrm{PS}_{4}^{3-}$ ion. Therefore, both $\mathrm{Na}^{+}$and $\mathrm{PS}_{4}^{3-}$ ions would diffuse readily by cold press, leading to better densification.

Retaining solid-solid contacts between active materials and SEs during charge-discharge processes brings about long cycle lives of all-solid-state batteries. Young's moduli of SEs are important for keeping favorable contacts even at volume changes of active materials. Those for densified sulfide electrolytes prepared by hot-pressing are determined by an ultrasonic pulse-echo technique and the uniaxial compression tests (Sakuda et al., 2013a,b; Nose et al., 2015). Young's moduli of the sulfide glasses in the systems $\mathrm{Li}_{2} \mathrm{~S}-\mathrm{P}_{2} \mathrm{~S}_{5}$ and $\mathrm{Na}_{2} \mathrm{~S}-\mathrm{P}_{2} \mathrm{~S}_{5}$ are presented in Figure $2 \mathbf{B}$. They are increased gradually with the increase in the alkali content in
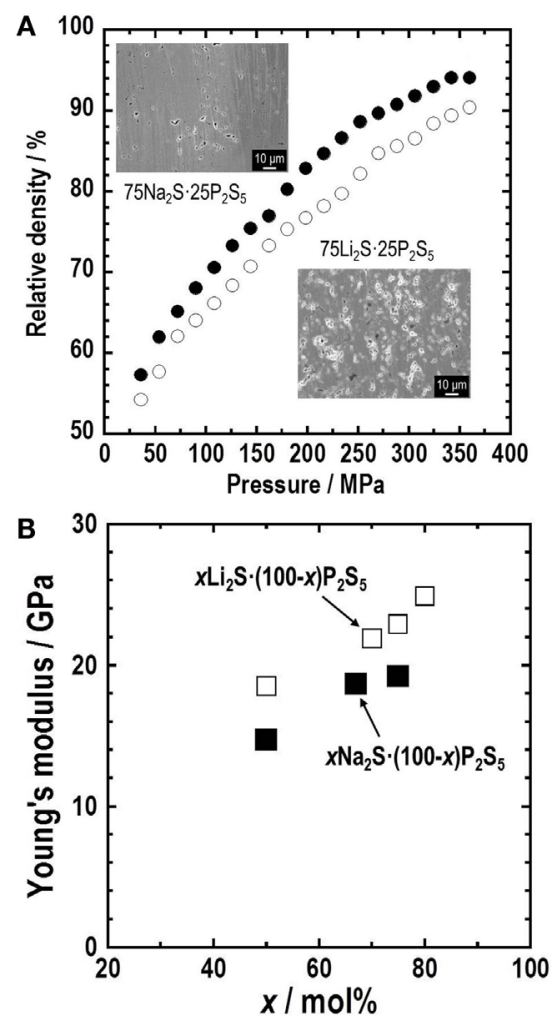

FIGURE 2 | (A) Molding pressure dependence of relative density of $75 \mathrm{M}_{2} \mathrm{~S} \cdot 25 \mathrm{P}_{2} \mathrm{~S}_{5}(\mathrm{M}=\mathrm{Li}$ or $\mathrm{Na}$, mol\%) glass electrolyte. Cross-sectional SEM images of these glass pellets prepared by pressing at $360 \mathrm{MPa}$ are also shown in the inset. (B) Composition dependence of Young's modulus for the $x \mathrm{M}_{2} \mathrm{~S} \cdot(100-x) \mathrm{P}_{2} \mathrm{~S}_{5}$ glasses. both systems. The $\mathrm{Na}_{2} \mathrm{~S}-\mathrm{P}_{2} \mathrm{~S}_{5}$ glasses have smaller Young's moduli of 15-19 GPa than the $\mathrm{Li}_{2} \mathrm{~S}-\mathrm{P}_{2} \mathrm{~S}_{5}$ glasses (18-25 GPa). The difference on Young's modulus is understood based on the Coulomb force and the mean atomic volume of the glasses. These sulfide glasses have an intermediate Young's modulus between oxide glasses and organic polymers. Sulfide electrolytes deforming elastically are expected to act as a buffer in response to volume changes of active materials during charge-discharge processes. In fact, most all-solid-state batteries that use sulfide SEs exhibit good cycle performance.

\section{Preparation Process}

Sulfide SEs were prepared via various techniques. Crystalline electrolytes are prepared via solid-phase reaction, whereas glass electrolytes are obtained using the melt-quenching method. In general, sulfide starting materials are sealed in a carbon-coated quartz tube under vacuum and then heat-treated because of high vapor pressure of sulfides at high temperatures. Heating temperatures and cooling rates at preparation process affect precipitated crystals. A phase diagram in ternary system $\mathrm{Li}_{2} \mathrm{~S}-\mathrm{GeS}_{2}-\mathrm{P}_{2} \mathrm{~S}_{5}$ is complicated (Hori et al., 2015), and crystalline $\mathrm{Li}_{10} \mathrm{GeP}_{2} \mathrm{~S}_{12}$ with a conductivity of $10^{-2} \mathrm{~S} \mathrm{~cm}^{-1}$ is prepared by selecting experimental conditions. Another preparation technique of sulfide electrolytes is mechanical milling using a high-energy planetary ball mill apparatus. This technique is fundamentally a room-temperature process. Therefore, sulfides are reacted at ordinary temperature and pressure. Electrolyte particles are obtained directly by milling. They are applicable to all-solid-state batteries without additional pulverization of electrolytes. Crystallization of glass electrolyte tends to precipitate a metastable phase, such as hightemperature phase, which generally has high ionic conductivity (Tatsumisago et al., 1991; Hayashi et al., 2003). Crystalline $\mathrm{Li}_{7} \mathrm{P}_{3} \mathrm{~S}_{11}$ (a high-temperature phase at the composition) is precipitated as a primary phase by heat treatment of a corresponding mother glass, and the obtained glass-ceramic electrolytes show conductivities of $10^{-3}-10^{-2} \mathrm{~S} \mathrm{~cm}^{-1}$, which depend on the degree of crystallinity and the grain boundary of $\mathrm{Li}_{7} \mathrm{P}_{3} \mathrm{~S}_{11}$ (Mizuno et al., 2005, 2006; Seino et al., 2014). Cubic $\mathrm{Na}_{3} \mathrm{PS}_{4}$ is crystallized from the $\mathrm{Na}_{3} \mathrm{PS}_{4}$ glass prepared by mechanical milling. The prepared glass-ceramic electrolytes with $\mathrm{Na}_{3} \mathrm{PS}_{4}$ show $\mathrm{Na}^{+}$ion conductivity of $10^{-4} \mathrm{~S} \mathrm{~cm}^{-1}$ at $25^{\circ} \mathrm{C}$ (Hayashi et al., 2012b).

Electrolyte preparation via liquid phase is a suitable process for cost-effective quantity synthesis without using a special reaction apparatus. In general, this process has benefits of lowering the reaction temperature, shortening the reaction time, and controlling the particle morphology and size. Prepared electrolyte solutions are also useful for the coating of active material particles. Very recently, liquid-phase synthesis of sulfide SEs has been reported. The reaction processes for sulfides are divided into two categories: one uses suspension and the other uses a homogeneous solution. For the former synthesis, $\beta-\mathrm{Li}_{3} \mathrm{PS}_{4}$ synthesized in tetrahydrofuran (Liu et al., 2013) or dimethyl carbonate (Phuc et al., 2016) as reaction medium and $\mathrm{Li}_{7} \mathrm{P}_{3} \mathrm{~S}_{11}$ synthesized in 1,2-dimethoxyethane (Ito et al., 2014) are reported. In these reactions, precursors with precipitates are obtained. Compressed pellets of the heat-treated sulfide electrolytes show conductivity of greater than $10^{-4} \mathrm{~S} \mathrm{~cm}^{-1}$ at $25^{\circ} \mathrm{C}$. As the latter one via 
homogeneous liquid, $\mathrm{Li}_{3} \mathrm{PS}_{4}$ is synthesized from a mixture of $\mathrm{Li}_{2} \mathrm{~S}$ and $\mathrm{P}_{2} \mathrm{~S}_{5}$ with $\mathrm{N}$-methlyformamide (NMF) (Teragawa et al., 2014a). The $\mathrm{Li}_{3} \mathrm{PS}_{4}$ SEs can also be prepared using a dissolutionreprecipitation process in NMF from $80 \mathrm{Li}_{2} \mathrm{~S} \cdot 20 \mathrm{P}_{2} \mathrm{~S}_{5}$ (mol\%) glass prepared in advance using mechanical milling (Teragawa et al., 2014b). The prepared $\mathrm{Li}_{3} \mathrm{PS}_{4}$ electrolyte shows low conductivity of $10^{-6} \mathrm{~S} \mathrm{~cm}^{-1}$ at the present stage, but conductivity can be enhanced by selecting electrolyte compositions. Argyrodide-type $\mathrm{Li}_{6} \mathrm{PS}_{5} \mathrm{Cl}$ is dissolved into ethanol. Then, the argyrodite phase is reprecipitated by removing ethanol at $80^{\circ} \mathrm{C}$ under vacuum for $3 \mathrm{~h}$ (Yubuchi et al., 2015a,b). A pellet of the product shows conductivity of $10^{-5} \mathrm{~S} \mathrm{~cm}^{-1}$ at $25^{\circ} \mathrm{C}$, which is somewhat lower than that of the original $\mathrm{Li}_{6} \mathrm{PS}_{5} \mathrm{Cl}$. Grain boundary resistance, which is affected by surface structure and morphology, might be greater in the prepared $\mathrm{Li}_{6} \mathrm{PS}_{5} \mathrm{Cl}$. Optimization of posttreatments for the prepared powders will enhance the $\mathrm{Li}_{6} \mathrm{PS}_{5} \mathrm{Cl}$ conductivity. Furthermore, the combination of sulfide SEs and ionic liquids produces pseudo-SEs (Minami et al., 2010; Oh et al., 2015). The prepared electrolytes give a new category of electrolytes having both high conductivity and good formability.

Sodium-ion conducting sulfide electrolytes with cubic $\mathrm{Na}_{3} \mathrm{PS}_{4}$ are also synthesized via a liquid-phase process from the mixture of $\mathrm{Na}_{2} \mathrm{~S}$ and $\mathrm{P}_{2} \mathrm{~S}_{5}$ in NMF solvent (Yubuchi et al., 2015a). The room-temperature conductivity of the obtained electrolyte is $10^{-6} \mathrm{~S} \mathrm{~cm}^{-1}$, which is lower than the conductivity of the electrolyte prepared by mechanical milling. Studies investigating sulfide SEs with $\mathrm{Na}^{+}$ion conductivity are extremely few at present. New electrolytes produced via a simple liquid-phase process will be researched widely.

\section{PREPARATION OF SOLID-SOLID INTERFACE IN ALL-SOLID-STATE BATTERIES}

Sulfide glasses are well-balanced SEs with high conductivity, good formability, appropriate Young's modulus, and moderate chemical stability. They are therefore highly promising SEs for use in all-solid-state batteries. A schematic diagram of bulk-type allsolid-state batteries is depicted in Figure 3. A positive electrode layer is composed not only of active material particles but also of $\mathrm{SE}$ ones. The $\mathrm{Li}^{+}$ion is supplied from SEs attached to active materials. Electrons are mobile through active materials. To enhance the rate of performance of the batteries, conductive additives of nanocarbons are added to the electrode layer. A lithium alloy or lithium metal is used as the negative electrode. A SE layer as a separator is sandwiched with the positive and negative electrode layers. Then, because of good formability of sulfide SEs, it can be pressed uniaxially at room temperature to fabricate bulk-type all-solid-state batteries.

An all-solid-state $\mathrm{In} / \mathrm{LiCoO}$ or $\mathrm{Li}-\mathrm{In} / \mathrm{Li}_{4} \mathrm{Ti}_{5} \mathrm{O}_{12}$ cell with $\mathrm{Li}_{2} \mathrm{~S}$ $\mathrm{P}_{2} \mathrm{~S}_{5}$ glass-ceramic electrolytes exhibits good cycle performance for hundreds of times at $25^{\circ} \mathrm{C}$ (Tatsumisago and Hayashi, 2008; Tatsumisago et al., 2013). These cells operate at a high temperature of $100^{\circ} \mathrm{C}$, where it is difficult for a liquid electrolyte cell to be used. The all-solid-state cell with $\mathrm{Li}_{4} \mathrm{Ti}_{5} \mathrm{O}_{12}$ shows a discharge-charge capacity of about $140 \mathrm{mAh} \mathrm{g}^{-1}$. It retains the capacity for 700

\section{Bulk-type battery}
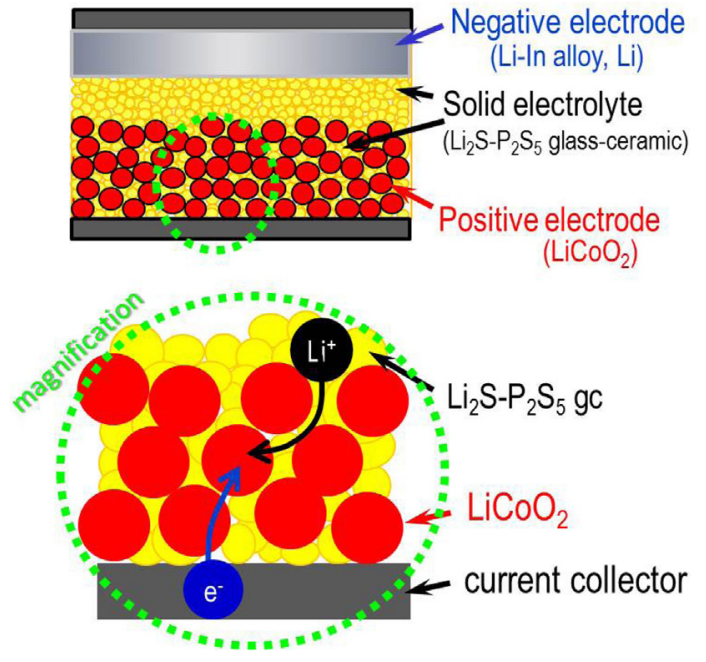

FIGURE 3 | Schematic diagram of bulk-type all-solid-state batteries.

cycles with no degradation under a high current density of more than $10 \mathrm{~mA} \mathrm{~cm}^{-2}$ (Minami et al., 2011).

\section{Coating of Sulfide Electrolytes on $\mathrm{LiCoO}_{2}$ and Graphite Particles}

Direct coating of sulfide SEs on $\mathrm{LiCoO}_{2}$ particles, instead of mixing electrolyte particles, is effective for forming good electrolyte- $\mathrm{LiCoO}_{2}$ interfaces with a wide contact area. Pulsed laser deposition (PLD) was first used as a coating technique (Sakuda et al., 2010, 2011). In this study, $\mathrm{LiNbO}_{3}$-coated $\mathrm{LiCoO}_{2}$ particles were fluidized with a vibrator to ensure uniform coating of sulfide electrolytes on the particles.

Figure 4 presents cross-sectional SEM images of positive electrodes with (a) a conventional mixture of $\mathrm{LiCoO}_{2}$ and $\mathrm{Li}_{2} \mathrm{~S}-\mathrm{P}_{2} \mathrm{~S}_{5}$ SE particles with the weight ratio of $70 / 30$ and (b) SE-coated $\mathrm{LiCoO}_{2}$ particles, where the weight ratio of $\mathrm{LiCoO}_{2}$ and SE coatings was 90/10. Figure $2 \mathrm{~A}$ shows that solid-solid contacts between $\mathrm{LiCoO}_{2}$ and SE are formed by cold pressing of the mixture electrode because SE particles are deformed easily by pressing. Figure $4 \mathrm{~A}$ shows that the aggregation of $\mathrm{LiCoO}_{2}$ particles engenders less utilization of $\mathrm{LiCoO}_{2}$ because many voids and less contact with SE are observed among $\mathrm{LiCoO}_{2}$ particles. A close-packed electrode layer is formed using only SE-coated $\mathrm{LiCoO}_{2}$ (Figure 4B). Its enlarged figure, which will be displayed in Figure 7D later, shows that a close solid-solid interface with fewer voids appears, and $\mathrm{Li}^{+}$ion conduction paths are therefore formed among $\mathrm{LiCoO}_{2}$ particles. It is noteworthy that SE amounts in the electrode are decreased considerably by SE coating on $\mathrm{LiCoO}_{2}$ particles. The use of minimum amounts of SE in an electrode layer contributes to enhanced energy density of all-solid-state batteries.

A cross-sectional high-angle annular dark field (HAADF)STEM image and EDX mappings of $\mathrm{O}, \mathrm{P}, \mathrm{S}, \mathrm{Co}$, and $\mathrm{Nb}$ elements for the SE-coated $\mathrm{LiCoO}_{2}$ electrodes are presented in Figure 5. A SE coating layer is observed between two $\mathrm{LiCoO}_{2}$ particles, 

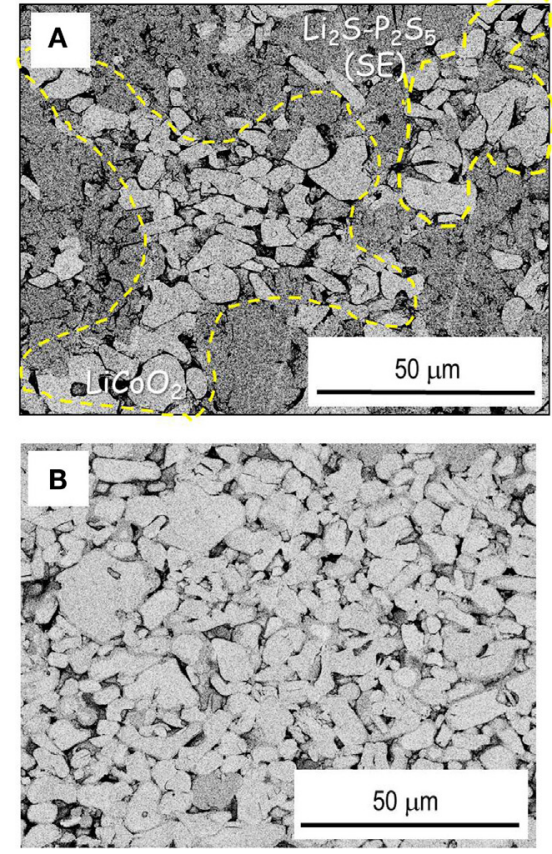

FIGURE 4 | Cross-sectional SEM images of $\mathrm{LiCoO}_{2}$ positive electrode layers consisting of (A) mixture electrode with $\mathrm{LiCoO}_{2}$ and $\mathrm{Li}_{2} \mathrm{~S}_{-}-\mathrm{P}_{2} \mathrm{~S}_{5}$ electrolyte particles and (B) electrolyte-coated $\mathrm{LiCoO}_{2}$ particles

where one particle has several cracks. The EDX mapping of $\mathrm{Nb}$ element reveals that a $\mathrm{LiNbO}_{3}$ coating layer exists on the surface of $\mathrm{LiCoO}_{2}$, but the layer is missing at the cracks. The EDX mappings of $\mathrm{P}$ and $\mathrm{S}$ elements indicate that SE penetrates into the cracks as a liquid electrolyte does. Favorable formability of sulfide $\mathrm{SE}$ is effective for forming good contacts with the surface of active materials and using active materials even at newly formed crystal faces with cracks.

Solid electrolyte coatings were also done for graphite particles using PLD. The mixture of SE-coated graphite and SE particles was used as a negative electrode. The weight ratio of graphite and $\mathrm{SE}$ was 90/10. All-solid-state cells with $\mathrm{Li}_{2} \mathrm{~S}-\mathrm{P}_{2} \mathrm{~S}_{5} \mathrm{SE}$ as a separator layer were charged and discharged at a constant current density of $0.064 \mathrm{~mA} \mathrm{~cm}{ }^{-2}$ (ca. $0.05 \mathrm{C}$ ) for voltages of $2.8-4.3$ or $4.6 \mathrm{~V}$ at room temperature (Sakuda et al., 2013b). Figure 6 shows charge-discharge curves for all-solid-state SE-coated graphite/ SE-coated $\mathrm{LiCoO}_{2}$ batteries. The battery with a cutoff voltage of $4.6 \mathrm{~V}$ at the charge process shows a higher discharge capacity than that of $4.3 \mathrm{~V}$. Battery has a discharge capacity of $133 \mathrm{mAh} \mathrm{g}^{-1}$, as calculated from the total mass of the composite positive electrode.

Figure 7 shows cross-sectional SEM images of SE-coated $\mathrm{LiCoO}_{2}$ positive electrodes; Figure 7A as-prepared, Figure 7B after the initial charge-discharge (cutoff voltage: $4.3 \mathrm{~V}$ ), and Figure 7C after the initial charge-discharge (cutoff voltage: $4.6 \mathrm{~V}$ ). Figures 7D-F, respectively, portray enlarged images of Figures 7A-C. Closely attached SE- $\mathrm{LiCoO}_{2}$ interfaces with large contact area are achieved by PLD coating, as shown in Figures 7A,D. The electrode morphology (Figure 7B) does not change greatly after the initial charge-discharge process at the cutoff of $4.3 \mathrm{~V}$. SE coatings still attach on the $\mathrm{LiCoO}_{2}$ particles (Figure 7E), and empty spaces among particles observed in panel (Figure 7B) are similar to those observed in the as-prepared electrode (Figure 7A). Figure 7C shows that voids among $\mathrm{LiCoO}_{2}$ particles increase after the charge-discharge process at a higher cutoff voltage of $4.6 \mathrm{~V}$. A $\mathrm{LiCoO}_{2}$ particle charged to $4.6 \mathrm{~V}$ suffers from deterioration. Many cracks are formed in the particle, as shown in the magnified image of panel (Figure 7F). This morphological change is attributable to (1) reduction of mechanical strength and (2) excess strain at the solid-solid interfaces among $\mathrm{LiCoO}_{2}$ particles during their large volume expansion and/or phase transition.

Figure 8 shows cross-sectional SEM images of SE-coated graphite negative electrodes; Figure $\mathbf{8 A}$ as-prepared and Figure $\mathbf{8 B}$ after the initial charge-discharge (cutoff voltage: $4.3 \mathrm{~V}$ ). Graphite particles are close-packed in a negative electrode layer. SE coatings are observed around graphite particles. They form $\mathrm{Li}^{+}$ion conduction paths through the electrode layer. After the initial charge-discharge, no obvious void is observed in the negative electrode. The close-packed electrode is present. Good solid-solid interfaces are also retained between the graphite layer and an electrolyte separator layer.

As described in Section "Preparation Process," liquid-phase synthesis of sulfide electrolytes is also useful for forming favorable electrode-electrolyte solid-solid interfaces, which can be achieved by removing solvents from electrolyte solutions. An all-solid-state cell using $\mathrm{LiCoO}_{2}$ coated with $\mathrm{Li}_{3} \mathrm{PS}_{4}$ electrolyte via an NMF solution operates as rechargeable batteries without the addition of SE and carbon-conductive additive particles to the positive electrodes (Teragawa et al., 2014a,b). However, the cell capacities are lower than those of the cells using $\mathrm{LiCoO}_{2}$ coated with $\mathrm{Li}_{3} \mathrm{PS}_{4}$ electrolytes by PLD, because the electrolytes synthesized via the liquid-phase has lower ionic conductivities than those prepared by PLD. The $\mathrm{LiCoO}_{2}$ particles coated with $\mathrm{Li}_{6} \mathrm{PS}_{5} \mathrm{Cl}$ electrolytes via ethanol solution with a higher conductivity than $\mathrm{Li}_{3} \mathrm{PS}_{4}$ were therefore applied to all-solid-state cells. The weight ratio of $\mathrm{LiCoO}_{2} / \mathrm{SE}$ layer was 92.5/7.5 in SE-coated $\mathrm{LiCoO}_{2}$ particles. An all-solidstate cell using the electrolyte-coated $\mathrm{LiCoO}_{2}$ shows an initial discharge capacity of $45 \mathrm{mAh} \mathrm{g}^{-1}$, which is greater than that of cells using $\mathrm{Li}_{3} \mathrm{PS}_{4}$-coated $\mathrm{LiCoO}_{2}$ (Yubuchi et al., 2015b). SE coating via electrolyte liquids is a simple and cost-effective process. Increasing conductivity of SE at lower temperatures is necessary to improve battery performance.

\section{Sulfur-Based Nanocomposite Positive Electrodes}

Sulfur is a fascinating positive electrode with high energy density because it is an abundant resource with high theoretical capacity of $1672 \mathrm{mAh} \mathrm{g}^{-1}$ and environmental friendliness. Lithium polysulfides $\left(\mathrm{Li}_{2} \mathrm{~S}_{x}\right)$, which are formed during discharge (lithiation process), are readily dissolved in organic liquid electrolytes, leading to lack of a sulfur positive electrode. Dissolution of lithium polysulfides is suppressed by absorbing sulfurs in nanocarbon pores. This approach has been studied extensively (Ji and Nazar, 2010). The use of inorganic SEs fundamentally resolves the problem. 


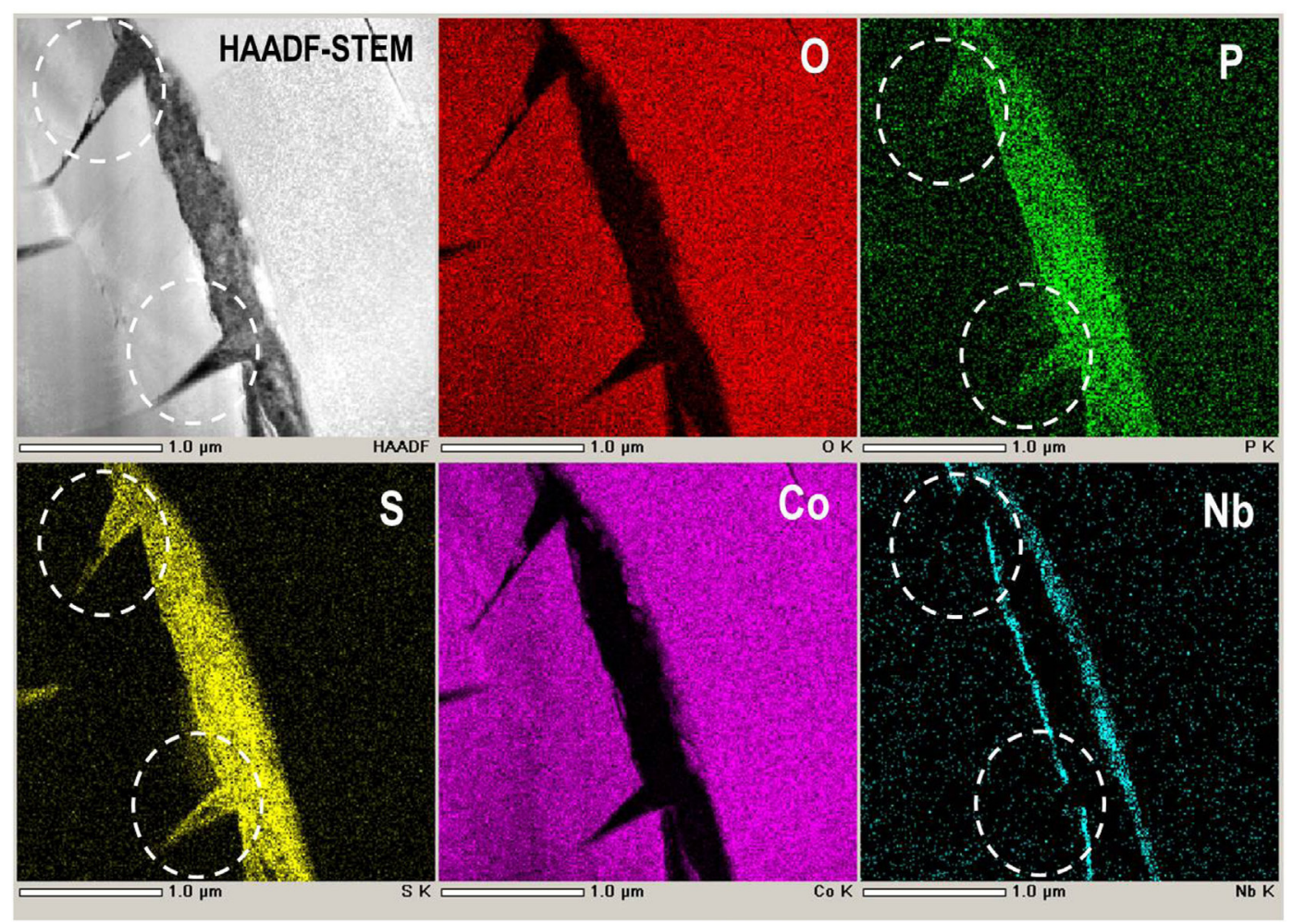

FIGURE 5 | Cross-sectional high-angle annular dark field (HAADF)-TEM image and EDX mappings of O, P, S, Co, and Nb elements for the SE-coated $\mathrm{LiCoO}_{2}$ electrodes.

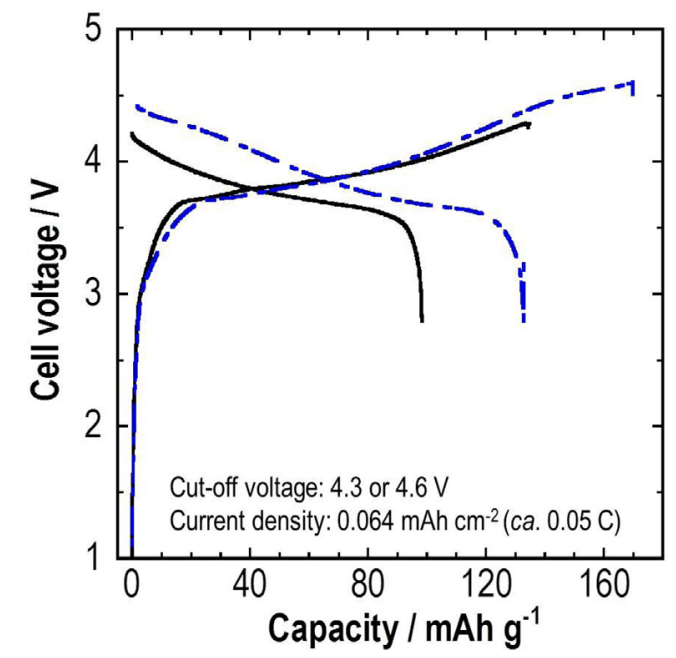

FIGURE 6 | Initial charge-discharge curves for an all-solid-state SE-coated graphite/SE-coated $\mathrm{LiCoO}_{2}$ battery.

Composite sulfur electrodes consisting of $\mathrm{S}$, acetylene black $(A B)$, and $\mathrm{Li}_{2} \mathrm{~S}-\mathrm{P}_{2} \mathrm{~S}_{5} \mathrm{SE}$ powders with a weight ratio of $25 / 25 / 50$ were prepared using high-energy planetary ball milling to produce favorable contacts among the three components (Nagao et al., 2011). The Li-In/S cell exhibits a large reversible capacity of greater than $1500 \mathrm{mAh} \mathrm{g}^{-1}$ of sulfur with average potential of ca. $2.1 \mathrm{~V}$ (vs. $\mathrm{Li}^{+} / \mathrm{Li}$ ). The cell with sulfur electrode shows 15 times higher capacity than the cell with $\mathrm{LiCoO}_{2}$, although the operating potential of the former cell is almost half that of the latter cell.

Application of $\mathrm{Li}_{2} \mathrm{~S}$ as a discharge product of sulfur active material offers the important benefits of high theoretical capacity of $1167 \mathrm{mAh} \mathrm{g}^{-1}$ and versatility of negative electrode materials without lithium sources. Because of the insulative nature of $\mathrm{Li}_{2} \mathrm{~S}$, composite electrodes, $\mathrm{Li}_{2} \mathrm{~S}$ mixed with conductive additives, such as nanocarbons and SEs, should be prepared for the use of $\mathrm{Li}_{2} \mathrm{~S}$ as an active material. Composite $\mathrm{Li}_{2} \mathrm{~S}$ electrodes were prepared by mechanical milling. A typical weight ratio of $\mathrm{Li}_{2} \mathrm{~S} /$ $\mathrm{AB} / \mathrm{Li}_{2} \mathrm{~S}_{-} \mathrm{P}_{2} \mathrm{~S}_{5} \mathrm{SE}$ is $25 / 25 / 50$. The prepared composite gives broad peaks attributable to $\mathrm{Li}_{2} \mathrm{~S}$ in $\mathrm{X}$-ray diffraction patterns. An all-solid-state cell of $\mathrm{In} / \mathrm{Li}_{2} \mathrm{~S}$ composites is charged and then discharged at $25^{\circ} \mathrm{C}$. The initial reversible capacity is $800 \mathrm{mAh} \mathrm{g}^{-1}$ at the current density of $0.064 \mathrm{~mA} \mathrm{~cm}^{-2}$ (Nagao et al., 2012b). The cell retained $750 \mathrm{mAh}^{-1}$ for 10 cycles. Charge-discharge reaction mechanisms were examined using high-resolution TEM observation (Nagao et al., 2015). Figure 9 shows TEM images for the $\mathrm{Li}_{2} \mathrm{~S}$ electrodes; Figure 9A before charge-discharge test, Figure 9B after the initial charge, and Figure 9C after the initial discharge. Figure 9A shows that nanoparticles of $c a .5 \mathrm{~nm}$ in size with different crystal orientations are distributed randomly in the matrix consisting of amorphous $\mathrm{SE}$ and $\mathrm{AB}$. Those nanoparticles are attributable to crystalline $\mathrm{Li}_{2} \mathrm{~S}$. Figure $9 \mathrm{~B}$ shows that no lattice fringes because of the crystalline $\mathrm{Li}_{2} \mathrm{~S}$ are apparent, and 


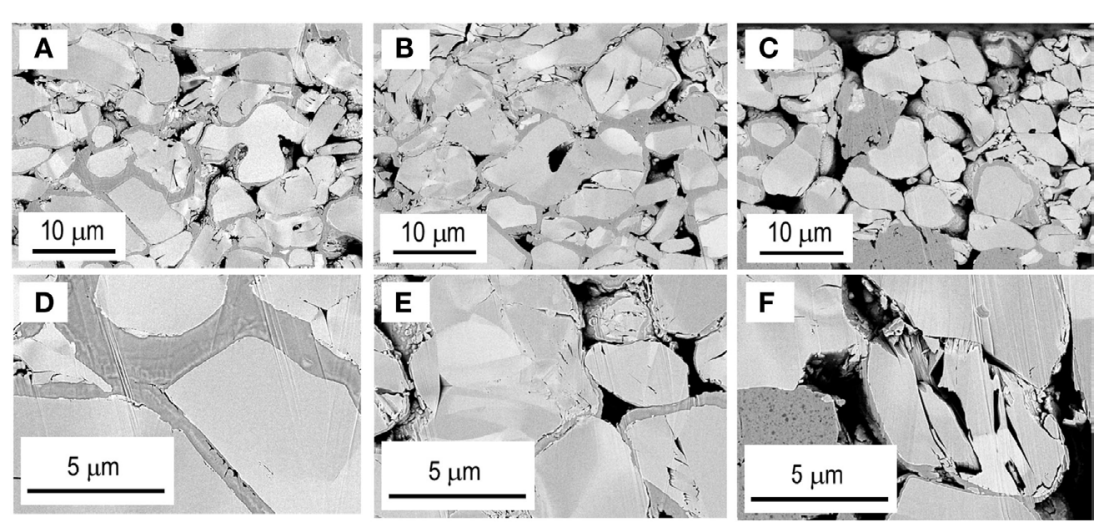

FIGURE 7 | Cross-sectional SEM images of SE-coated $\mathrm{LiCoO}_{2}$ positive electrodes (A) as-prepared, (B) after the initial charge-discharge (cutoff voltage: $4.3 \mathrm{~V}$ ), and (C) after the initial charge-discharge (cutoff voltage: $4.6 \mathrm{~V}$ ). Images of (D-F), respectively, depict enlarged images of (A-C).

there exists the characteristic contrast attributable to amorphous structure in the whole region after the initial charge process. As shown in Figure 9C, lattice fringes with spacing of about $3.9 \AA$ are clearly apparent after the initial discharge, suggesting that amorphous sulfur is converted into crystalline nanoparticles during discharge reaction. Reversible transformation between crystallization and amorphization of sulfur-based active nanoparticles is responsible for the high capacity and its retention.

The utilization of $\mathrm{Li}_{2} \mathrm{~S}$ is ca. $50 \%$ in the composite electrode. To increase the utilization of $\mathrm{Li}_{2} \mathrm{~S}$, one strategy is the fundamental enhancement of ionic conductivity in $\mathrm{Li}_{2} \mathrm{~S}$. A partial substitution of more polarizable iodide anion with larger ionic radii for sulfide anion in $\mathrm{Li}_{2} \mathrm{~S}$ is expected to increase conductivity by introducing lithium vacancies and by increasing the lattice constant. Solid solutions in the system $\mathrm{Li}_{2} \mathrm{~S}$ - $\mathrm{LiI}$ are therefore prepared using mechanical milling (Hakari et al., 2015a). Only the XRD peaks attributable to $\mathrm{Li}_{2} \mathrm{~S}$ are observed; LiI peaks disappear completely in the composition range of $0<\mathrm{LiI}(\mathrm{mol} \%)<20$. Figure $10 \mathrm{~A}$ presents the composition dependence of lattice constant and conductivity at $25^{\circ} \mathrm{C}$ for the prepared $\mathrm{Li}_{2} \mathrm{~S}$ - $\mathrm{LiI}$ materials. The lattice constant increases monotonically with increased LiI content, suggesting that $\mathrm{Li}_{2} \mathrm{~S}$-based solid solutions are prepared using a mechanical milling process. Conductivity is also enhanced by increasing the LiI content. The solid solution with $20 \mathrm{~mol} \% \mathrm{LiI}$ has conductivity of $2.2 \times 10^{-6} \mathrm{~S} \mathrm{~cm}^{-1}$, which is two orders of magnitude higher than that for $\mathrm{Li}_{2} \mathrm{~S}$ itself without the addition of LiI. A composite positive electrode with the $80 \mathrm{Li}_{2} \mathrm{~S} \cdot 20 \mathrm{LiI}$ (mol\%) solid solution, vapor-grown carbon fiber (VGCF), and $\mathrm{Li}_{3} \mathrm{PS}_{4}$ glass electrolyte with a weight ratio of 50/10/40 is applied to all-solidstate cells. Figure 10B shows that an all-solid-state cell (Li-In/ $\left.\mathrm{Li}_{3} \mathrm{PS}_{4} / 80 \mathrm{Li}_{2} \mathrm{~S} \cdot 20 \mathrm{LiI}\right)$ is charged and discharged at a current density of $0.13 \mathrm{~mA} \mathrm{~cm}^{-2}(0.07 \mathrm{C})$ at $25^{\circ} \mathrm{C}$. The cell shows a reversible capacity of $930 \mathrm{mAh} \mathrm{g}^{-1}$ for 50 cycles. The capacity corresponds to $80 \%$ utilization of $\mathrm{Li}_{2} \mathrm{~S}$. It is noteworthy that the enhancement of conductivity of $\mathrm{Li}_{2} \mathrm{~S}$ is effective for increasing the utilization of the active material. This strategy is beneficial for the development of all-solid-state cells with a higher energy density.

A SE $\mathrm{Li}_{3} \mathrm{PS}_{4}$ is ball-milled with nanocarbon, such as $\mathrm{AB}$. The prepared $\mathrm{Li}_{3} \mathrm{PS}_{4}-\mathrm{AB}$ materials as a mixed conductor are useful as positive electrode acting not only as a SE but also as an active material. An all-solid-state cell with the $\mathrm{Li}_{3} \mathrm{PS}_{4}-\mathrm{AB}$ composite positive electrode is charged and discharged. Its operation voltage of ca. 2.6 V vs. $\mathrm{Li}^{+} / \mathrm{Li}$ is somewhat higher than that of $\mathrm{Li}_{2} \mathrm{~S}$ (Hakari et al., 2015b). Redox-active electrolytes, such as $\mathrm{CuCl}_{2}$-dissolved solution in porous carbons, are also reported to apply to supercapacitors (Mai et al., 2013). The use of the SEs as an active material in electrode layers is effective at increasing the reversible capacity per gram of the total mass of positive electrodes.

\section{Transition Metal Sulfide Positive Electrodes}

Typical $\mathrm{MS}_{x}$, such as $\mathrm{TiS}_{2}$, are used as active materials in allsolid-state $\mathrm{Li}$ and $\mathrm{Na}$ batteries with sulfide SEs. Decreasing the particle size of $\mathrm{MS}_{x}$ and forming a wide contact area with both SEs and conductive additives are important for increasing the $\mathrm{MS}_{x}$ utilization.

Monodispersed $\mathrm{MS}_{x}$ nanoparticles are prepared using a socalled "hot-soap" technique using high-boiling point solvents as a reaction medium. Particle morphology and size can be controlled by choosing the reaction conditions and combinations of coordinating or non-coordinating solvents. NiS particles of $50 \mathrm{~nm}$ size were prepared using thermal decomposition of nickel acetylacetonate in a mixed solution of 1-dodecanethiol as a sulfur source and 1-octadecene as a non-coordinating solvent at $280^{\circ} \mathrm{C}$ for $5 \mathrm{~h}$ (Aso et al., 2011). The NiS nanoparticles are crystallized directly on a carbon fiber (VGCF) by adding VGCF to a liquid medium. Good adhesion between NiS and carbon is achieved (Aso et al., 2012). Sulfide electrolyte coating on NiS-VGCF was produced using the PLD method. All-solid-state cells with the prepared NiS composite electrode operate as a secondary battery at $25^{\circ} \mathrm{C}$, suggesting that electron and $\mathrm{Li}^{+}$ion conduction paths are formed in the composite electrodes (Aso et al., 2013).

To increase the positive electrode capacity, sulfur-rich $\mathrm{MS}_{x}$ are desired. For example, titanium trisulfide $\mathrm{TiS}_{3}$ shows a higher capacity than that of $\mathrm{TiS}_{2}$, because additional sulfurs in $\mathrm{TiS}_{3}$ contribute to the redox reaction that occurs during charge-discharge processes (Hayashi et al., 2012a). Amorphous $\operatorname{NbS}_{x}(x=3,4,5)$ 


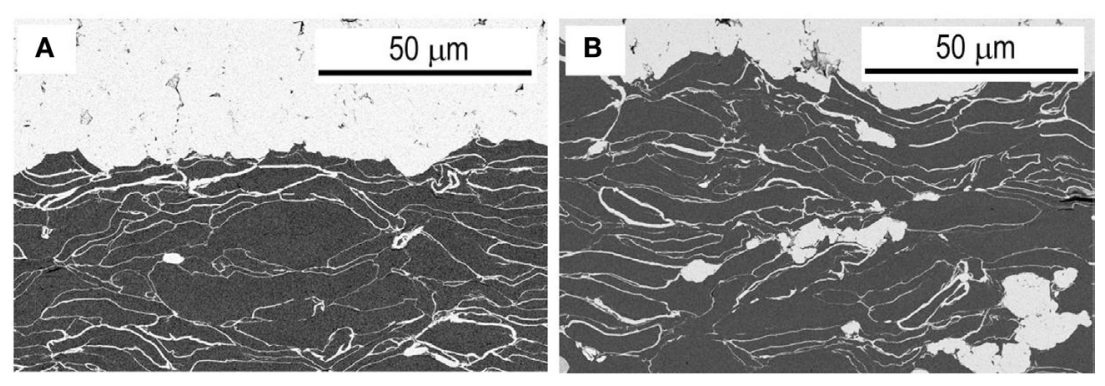

FIGURE 8 | Cross-sectional SEM images of SE-coated graphite negative electrodes (A) as-prepared and (B) after the initial charge-discharge (cutoff voltage: $4.3 \mathrm{~V}$ )
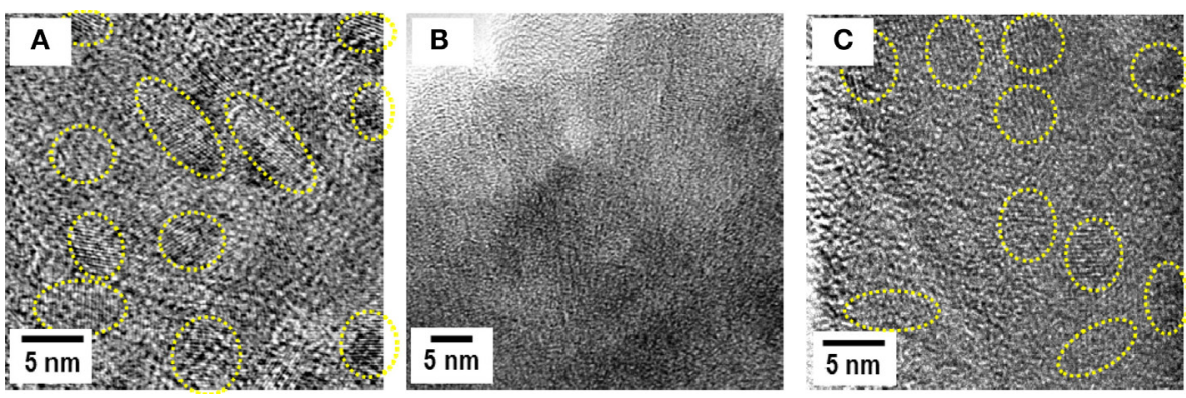

FIGURE 9 | TEM images for the $\mathrm{Li}_{2} \mathrm{~S}$ electrodes (A) before charge-discharge test, (B) after the initial charge, and (C) after the initial discharge

are prepared mechanochemically. Electrochemical cells with an organic liquid electrolyte using the amorphous $\operatorname{NbS}_{x}(x=3,4,5)$ show higher discharge capacities with an increase in the sulfur content of $\mathrm{NbS}_{\mathrm{x}}$ (Sakuda et al., 2014). Amorphous $\mathrm{TiS}_{3}\left(a-\mathrm{TiS}_{3}\right)$ retains a higher capacity than crystalline $\mathrm{TiS}_{3}$ in all-solid-state lithium cells. The crystal structure of $\mathrm{TiS}_{3}$ is partially deteriorated at the initial cycle, leading to an irreversible capacity in the cell with crystalline $\mathrm{TiS}_{3}$ (Matsuyama et al., 2016a,b). It is noteworthy that sulfur-rich amorphous $\mathrm{MS}_{x}$ with electrical conductivity are promising for use as positive electrodes instead of sulfur active materials.

Figure 11A shows the first and tenth charge-discharge curves of all-solid-state lithium cell $\mathrm{Li}-\mathrm{In} / a-\mathrm{TiS}_{3}$ at $0.013 \mathrm{~mA} \mathrm{~cm} \mathrm{~cm}^{-2}$ at $25^{\circ} \mathrm{C}$. The right side ordinate axis represents the electrode potential vs. $\mathrm{Li}^{+} / \mathrm{Li}$, as calculated based on the potential difference between the Li-In and Li electrode $(0.62 \mathrm{~V})$. The cell with $a-\mathrm{TiS}_{3}$ positive electrode including no carbon-conductive additives and SEs shows a reversible capacity for 10 cycles of about $510 \mathrm{mAh} \mathrm{g}^{-1}$ of $a-\mathrm{TiS}_{3}$, which equals the weight of the total positive electrode. The capacity corresponds to storage of about $3 \mathrm{M} \mathrm{Li}$ to $a-\mathrm{TiS}_{3}$. Electronic structural analyses using S2p XPS and S K-edge XANES reveal that a reversible sulfur redox in $a$-TiS $S_{3}$ appears mainly during charge-discharge processes and contributes to its good capacity retention (Matsuyama et al., 2016a,b).

Amorphous $\mathrm{TiS}_{3}$ is also applicable to all-solid-state sodium batteries. An all-solid-state sodium cell using $a-\mathrm{TiS}_{3}$ shows capacity higher than $300 \mathrm{mAh} \mathrm{g}^{-1}$ at the first discharge process, as presented in Figure 11B (Tanibata et al., 2015a). The composite positive electrode consisting of $a-\mathrm{TiS}_{3}$ and the cubic $\mathrm{Na}_{3} \mathrm{PS}_{4}$ electrolyte with a weight ratio of $40 / 60$ is used. $\mathrm{Na}_{15} \mathrm{Sn}_{4}$ alloy and the cubic $\mathrm{Na}_{3} \mathrm{PS}_{4}$ electrolyte are used, respectively, as a negative electrode and a separator layer. The cell capacity decreases gradually during discharge-charge cycles. SEM-EDX analysis reveals that the $a-\mathrm{TiS}_{3}$ particles aggregate after the cycles, and that resistance in the $a-\mathrm{TiS}_{3}$ composite electrode increases during cycles. To secure electron conduction paths to $a-\mathrm{TiS}_{3}, 6 \mathrm{wt} \% \mathrm{AB}$ is added to the positive electrode. Good capacity retention is achieved in the cell using $a-\mathrm{TiS}_{3}$ electrode with $\mathrm{AB}$. The added $\mathrm{AB}$ particles might prevent the shutoff of electron conduction paths in the composite electrode and give a buffer space for the volume change of $a-\mathrm{TiS}_{3}$ particles for preserving adhesion among the particles. The addition of $\mathrm{AB}$ to the $\mathrm{Na}_{15} \mathrm{Sn}_{4}$ electrode also suppresses cell resistance after charge-discharge. In addition, the replacement of $\mathrm{Na}_{3} \mathrm{PS}_{4}$ glass-ceramic by $94 \mathrm{Na}_{3} \mathrm{PS}_{4} \cdot 6 \mathrm{Na}_{4} \mathrm{SiS}_{4}(\mathrm{~mol} \%)$ glass-ceramic with higher conductivity decreases cell resistance and increases the rate performance of all-solid-state cells (Tanibata et al., 2015b). Reversible capacity in all-solid-state $\mathrm{Na}$ cells is less than that in all-solid-state Li cells, as shown in Figures 11A,B. The lower conductivity of SEs and loss of particle contacts because of the larger volume change are responsible for a smaller capacity for the Na cells. Approaches that are used to prepare composite positive electrodes suitable for insertion/de-insertion of $\mathrm{Na}^{+}$ion with larger ionic radius must be developed to improve battery performance in all-solid-state $\mathrm{Na}$ batteries. 

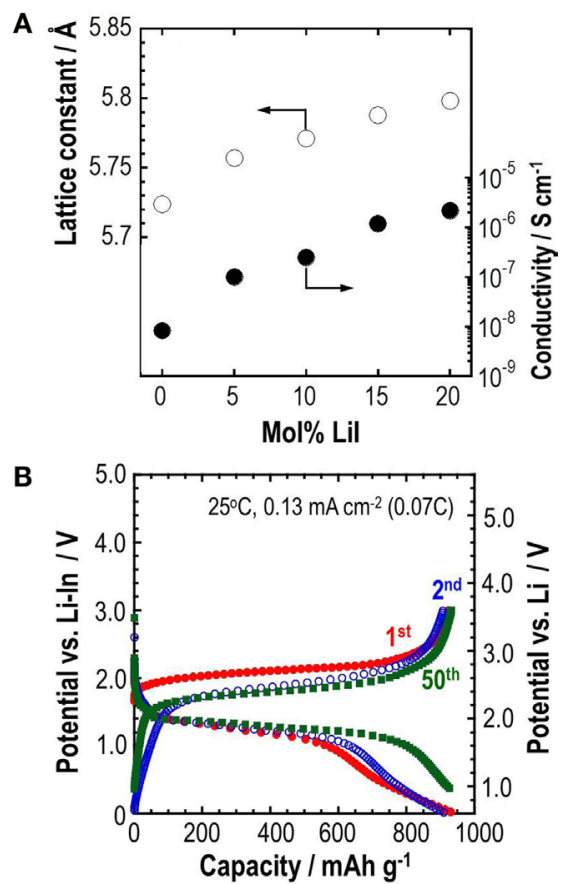

FIGURE 10 | (A) Composition dependence of lattice constant and conductivity at $25^{\circ} \mathrm{C}$ for prepared $\mathrm{Li}_{2} \mathrm{~S}$-Lil solid solutions and (B) chargedischarge curves of an all-solid-state cell (Li-In/Li $\left.\mathrm{PS}_{4} / 80 \mathrm{Li}_{2} \mathrm{~S} \cdot 2 \mathrm{OLil}\right)$.

\section{Interface Modification for Li Metal Negative Electrode}

To achieve high energy density of all-solid-state Li batteries, the final goal is the use of lithium metal as a negative electrode. Lithium metal is an ultimate negative electrode because of a large theoretical capacity of $3861 \mathrm{mAh} \mathrm{g}^{-1}$ and the lowest electrochemical potential of $-3.04 \mathrm{~V}$ vs. SHE. However, a possibility of fatal problems emerged by short-circuit with dendrite formation prevent the practical use of Li metal negative electrode in lithium cells with conventional liquid and polymer electrolytes. Combination with inorganic SEs is expected to resolve the problem. In fact, thin-film solid-state batteries with $\mathrm{Li}$ negative electrode have excellent cycle life without capacity fading (Bates et al., 1993). The rate of utilization of Li electrodes is not high in thin-film batteries because positive electrodes such as $\mathrm{LiCoO}_{2}$ have lithium sources, which are mainly used for a charge-discharge process.

Compared with thin-film batteries fabricated by gas-phase deposition, insufficient Li-SE interfaces in bulk-type all-solidstate batteries prepared by cold pressing are important issues that must be resolved. It has been revealed by in situ SEM observation that lithium is deposited through grain boundaries and voids in the SE (Nagao et al., 2013). Insertion of a Li-alloy thin layer at the interface between the Li electrode and SE layers brought about stable Li dissolution and deposition in the allsolid-state Li metal cells (Hiratani et al., 1988; Okita et al., 2011; Nagao et al., 2012a). These interface modifications are effective at establishing homogeneous interfaces between the Li metal and SEs.
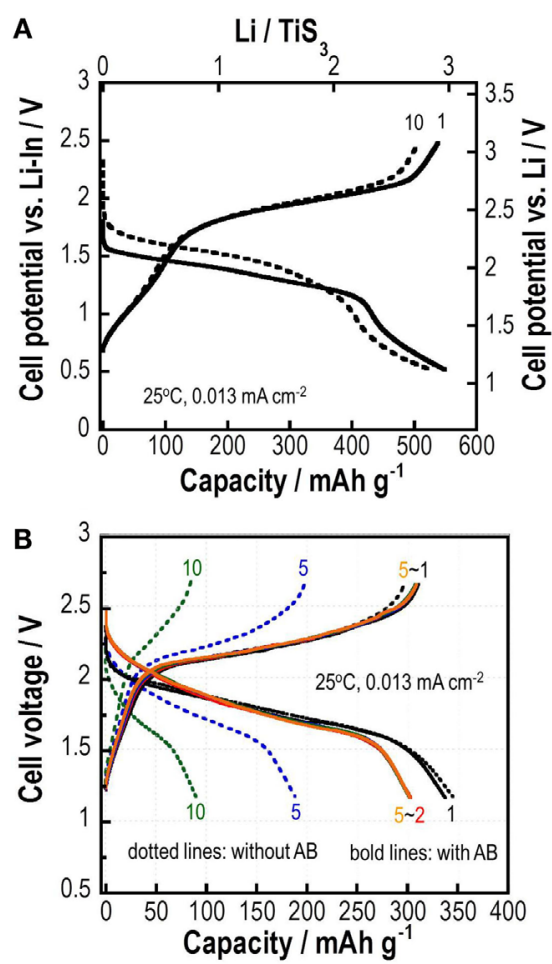

FIGURE 11 | (A) Charge-discharge curves of all-solid-state lithium cell Li-In/ amorphous $\mathrm{TiS}_{3}$ and (B) charge-discharge curves of all-solid-state sodium cell $\mathrm{Na}_{15} \mathrm{Sn}_{4}$ /amorphous $\mathrm{TiS}_{3}$ with or without $\mathrm{AB}$.

Intensive utilization of $\mathrm{Li}$ is important for achieving high energy density of all-solid-state lithium metal batteries. Insertion of a Au thin film at the Li-SE interface is effective for increasing $\mathrm{Li}$ utilization (Kato et al., 2016a). Li and Au thin films were formed on a pelletized $\mathrm{Li}_{3} \mathrm{PS}_{4}$ glass electrolyte by vacuum evaporation. Galvanostatic cycling tests for the $\mathrm{Li} / \mathrm{Li}_{3} \mathrm{PS}_{4} / \mathrm{Li}$ cell are presented in Figure 12A. At the initial cycle, the utilization of Li metal is about $40 \%$, which is a higher rate of utilization of Li metal for thin-film batteries (about 20\%). However, utilization of Li metal for the cell decreases rapidly after five cycles. The Li thin-film morphology is rough after galvanostatic cycling tests, as shown in the SEM image (Figure 12C), indicating that inhomogeneous Li dissolution-deposition reactions occur. The cell $\mathrm{Li} / \mathrm{Au} / \mathrm{Li}_{3} \mathrm{PS}_{4} / \mathrm{Au} / \mathrm{Li}$ has about $35 \% \mathrm{Li}$ utilization at the initial cycle and retains about $25 \%$ after the fifth cycle, as presented in Figure 12B. The morphology of $\mathrm{Li}$ metal after Li dissolution-deposition reaction became more uniform, as shown in the SEM image of panel (Figure 12D), compared with the cell without $\mathrm{Au}$ thin films. The insertion of Au film to a $\mathrm{Li}-\mathrm{SE}$ interface is a first step for improving the cyclability of Li deposition-dissolution reactions with high Li utilization in allsolid-state lithium metal batteries. Intensive studies are in progress.

\section{CONCLUDING REMARKS}

We have reviewed recent developments related to sulfide SEs and interface formation processes for all-solid-state rechargeable batteries. The conductivity of sulfide $\mathrm{Li}^{+}$ion conductors, such as 

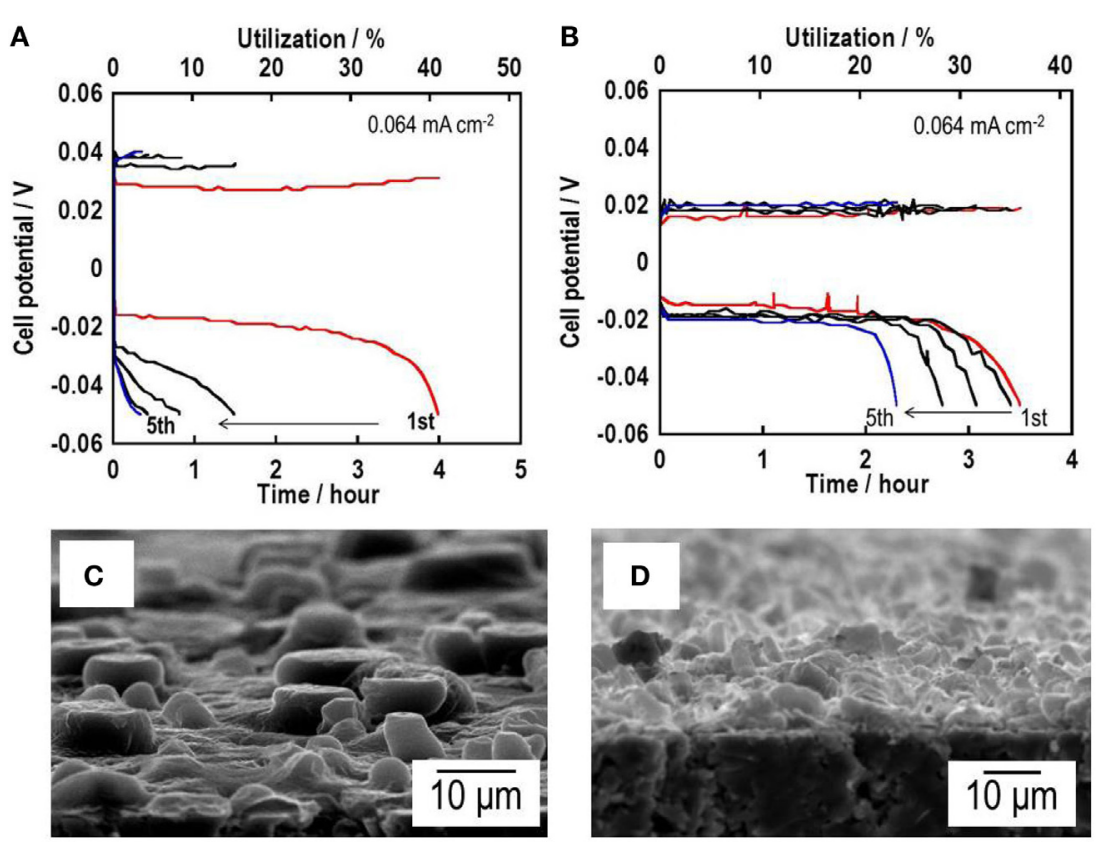

FIGURE 12 | Galvanostatic cycling tests for (A) a Li symmetric $\mathrm{Li}^{\prime} \mathrm{Li}_{3} \mathrm{PS}_{4} / \mathrm{Li}$ cell and (B) a $\mathrm{Li} / \mathrm{Au}^{\prime} / \mathrm{Li}_{3} \mathrm{PS}_{4} / \mathrm{Au} / \mathrm{Li}$ cell. SEM images of the surface of (C) a Li/ $\mathrm{Li}_{3} \mathrm{PS}_{4} / \mathrm{Li}$ cell and (D) a Li/Au/Li3 $\mathrm{PS}_{4} / \mathrm{Au} / \mathrm{Li}$ cell after galvanostatic cycling tests.

$\mathrm{Li}_{10} \mathrm{GeP}_{2} \mathrm{~S}_{12}, \mathrm{Li}_{7} \mathrm{P}_{3} \mathrm{~S}_{11}$, and $\mathrm{Li}_{9.54} \mathrm{Si}_{1.74} \mathrm{P}_{1.44} \mathrm{~S}_{11.7} \mathrm{Cl}_{0.3}$, has already reached $10^{-2} \mathrm{~S} \mathrm{~cm}^{-1}$ at room temperature. Conductivities of sulfide $\mathrm{Na}^{+}$ ion conductors are lower than those of $\mathrm{Li}^{+}$ion conductors at the present stage. The highest conductivity of $10^{-3} \mathrm{~S} \mathrm{~cm}^{-1}$ was obtained for $\mathrm{Na}_{3} \mathrm{PSe}_{4}$. Sulfide glass electrolytes with high alkali content were prepared by high-energy ball milling process. Metastable phases, such as $\mathrm{Li}_{7} \mathrm{P}_{3} \mathrm{~S}_{11}$ and cubic $\mathrm{Na}_{3} \mathrm{PS}_{4}$, with high conductivity were formed by careful crystallization of the prepared glasses. Sulfide electrolytes can be synthesized via liquid-phase processing, which is useful for coating application. Sulfide glass electrolytes have favorable formability, and Young's modulus for forming good electrode-electrolyte interfaces achieving rapid charge transfer in bulk-type all-solid-state batteries. Chemical stability in air is a great shortcoming of using a sulfide electrolyte. The composition of $\mathrm{Li}_{3} \mathrm{PS}_{4}$ has superior chemical stability in the $\mathrm{Li}_{2} \mathrm{~S}-\mathrm{P}_{2} \mathrm{~S}_{5}$ binary system. The higher chemical stability is achieved by partial substitution of oxygen for sulfur. Selecting composition and designing structure for sulfide electrolytes is expected to improve conductivity, mechanical properties, and chemical stability further. As $\mathrm{Na}^{+}$ ion conductors, higher conductivity of more than $10^{-2} \mathrm{~S} \mathrm{~cm}^{-1}$ is predicted for $\mathrm{Sn}$-substituted cubic $\mathrm{Na}_{3} \mathrm{PS}_{4}$, but the conductivity has not been achieved experimentally. Further studies seeking new electrolytes and suitable preparation processes must be undertaken.

Coating of SE and preparation of nanocomposites are useful for forming favorable solid-solid interface in an electrode layer for bulk-type all-solid-state batteries. Coating of sulfide electrolytes on $\mathrm{LiCoO}_{2}$ or graphite particles using gas-phase or liquid-phase techniques is effective for increasing solid-solid contact area using extremely small amounts of electrolytes. Preparation of nanocomposites using high-energy ball milling is useful for sulfur or $\mathrm{Li}_{2} \mathrm{~S}$ active materials with an insulative nature. Conductivity enhancement of $\mathrm{Li}_{2} \mathrm{~S}$ by combination with $\mathrm{LiI}$ contributes to the improvement of $\mathrm{Li}_{2} \mathrm{~S}$ utilization. Amorphous $\mathrm{MS}_{x}$, such as amorphous $\mathrm{TiS}_{3}$, are attractive as mixed conductors with large capacity in all-solid-state batteries. Interface modification for $\mathrm{Li}$ metal negative electrode with Au thin film improves the cycle performance of Li dissolution-deposition while maintaining a high rate of utilization. For further improvement of electrochemical performance of the batteries, facile approaches achieving favorable electrode-electrolyte interfaces with large contact area will be developed. Controlling the size, morphology, and dispersibility of both electrolyte and electrode particles and selecting suitable electrolytes for maintaining close solid-solid contacts during charge-discharge processes will be assessed in future studies.

\section{AUTHOR CONTRIBUTIONS}

AH contributed to the preparation of the manuscript. AS and MT contributed to the discussions about research results.

\section{ACKNOWLEDGMENTS}

This research is supported by a Grant-in-Aid for Scientific Research from the Ministry of Education, Culture, Sports, Science and Technology (MEXT) of Japan. In particular, the research about all-solid-state Li batteries was financially supported by the Japan Science and Technology Agency (JST), Advanced Low Carbon Technology Research and Development Program (ALCA), Specially Promoted Research for Innovative Next Generation Batteries (SPRING) Project, while the research about all-solid-state Na batteries was supported by the MEXT program "Elements Strategy Initiative for Catalysts and Batteries (ESICB)." 


\section{REFERENCES}

Aotani, N., Iwamoto, K., Takada, K., and Kondo, S. (1994). Synthesis and electrochemical properties of lithium ion conductive glass, $\mathrm{Li}_{3} \mathrm{PO} 4-\mathrm{Li}_{2} \mathrm{~S}-\mathrm{SiS}_{2}$. Solid State Ionics. 68, 35-39. doi:10.1016/0167-2738(94)90232-1

Aso, K., Hayashi, A., and Tatsumisago, M. (2012). Synthesis of NiS-carbon fiber composites in high-boiling solvent to improve electrochemical performance in all-solid-state lithium secondary batteries. Electrochim. Acta 83, 448-453. doi:10.1016/j.electacta.2012.07.088

Aso, K., Kitaura, H., Hayashi, A., and Tatsumisago, M. (2011). Synthesis of nanosized nickel sulfide in high-boiling solvent for all-solid-state lithium secondary batteries. J. Mater. Chem. 21, 2987-2990. doi:10.1039/ c0jm02639e

Aso, K., Sakuda, A., Hayashi, A., and Tatsumisago, M. (2013). All-solid-state lithium secondary batteries using NiS-carbon fiber composite electrodes coated with $\mathrm{Li}_{2} \mathrm{~S}-\mathrm{P}_{2} \mathrm{~S}_{5}$ solid electrolytes by pulsed laser deposition. ACS Appl. Mater. Interfaces 5, 686-690. doi:10.1021/am302164e

Bates, J., Dudney, N., Gruzalski, G., Zuhr, R., Choudhury, A., and Luck, C. (1993). Fabrication and characterization of amorphous lithium electrolyte thin films and rechargeable thin-film batteries. J. Power Sources 4, 103-110. doi:10.1016/0378-7753(93)80106-Y

Boron, P., Johansson, S., Zick, K., Gunne, J., Dehnen, S., and Roling, B. (2013). $\mathrm{Li}_{10} \mathrm{SnP}_{2} \mathrm{~S}_{12}$ : an affordable lithium superionic conductor. J. Am. Chem. Soc. 135, 15694-15697. doi:10.1021/ja407393y

Boulineau, S., Courty, M., Tarascon, J. M., and Viallet, V. (2012). Mechanochemical synthesis of $\mathrm{Li}$-argyrodite $\mathrm{Li}_{6} \mathrm{PS}_{5} \mathrm{X}(\mathrm{X}=\mathrm{Cl}, \mathrm{Br}, \mathrm{I})$ as sulfur-based solid electrolytes for all solid state batteries application. Solid State Ionics. 221, 1-5. doi:10.1016/j. ssi.2012.06.008

Hakari, T., Hayashi, A., and Tatsumisago, M. (2015a). Highly utilized lithium sulfide active material by enhancing conductivity in all-solid-state batteries. Chem. Lett. 44, 1664-1666. doi:10.1246/cl.150758

Hakari, T., Nagao, M., Hayashi, A., and Tatsumisago, M. (2015b). All-solid-state lithium batteries with $\mathrm{Li}_{3} \mathrm{PS}_{4}$ glass as active material. J. Power Sources 293, 721-725. doi:10.1016/j.jpowsour.2015.05.073

Hayashi, A., Hama, S., Minami, T., and Tatsumisago, M. (2003). Formation of superionic crystals from mechanically milled $\mathrm{Li}_{2} \mathrm{~S}-\mathrm{P}_{2} \mathrm{~S}_{5}$ glasses. Electrochem. Commun. 5, 111-114. doi:10.1016/S1388-2481(02)00555-6

Hayashi, A., Matsuyama, T., Sakuda, A., and Tatsumisago, M. (2012a). Amorphous titanium sulfide electrode for all-solid-state rechargeable lithium batteries with high capacity. Chem. Lett. 41, 886-888. doi:10.1246/cl.2012.886

Hayashi, A., Noi, K., Sakuda, A., and Tatsumisago, M. (2012b). Superionic glassceramic electrolytes for room-temperature rechargeable sodium batteries. Nat. Commun. 3, 1-5. doi:10.1038/ncomms 1843

Hayashi, A., Muramatsu, H., Ohtomo, T., Hama, S., and Tatsumisago, M. (2013). Improvement of chemical stability of $\mathrm{Li}_{3} \mathrm{PS}_{4}$ glass electrolytes by adding $\mathrm{M}_{\mathrm{x}} \mathrm{O}_{\mathrm{y}}$ ( $\mathrm{M}=\mathrm{Fe}, \mathrm{Zn}$, and $\mathrm{Bi}$ ) nanoparticles. J. Mater. Chem. A 1, 6320-6326. doi:10.1039/ c3ta10247e

Hiratani, M., Miyauchi, K., and Kudo, T. (1988). Effect of a lithium alloy layer inserted between a lithium anode and a solid electrolyte. Solid State Ionics. 2, 1406-1410. doi:10.1016/0167-2738(88)90394-3

Hori, S., Kato, M., Suzuki, K., Hirayama, M., Kato, Y., and Kanno, R. (2015). Phase diagram of the $\mathrm{Li}_{4} \mathrm{GeS}_{4}-\mathrm{Li}_{3} \mathrm{PS}_{4}$ quasi-binary system containing the superionic conductor $\mathrm{Li}_{10} \mathrm{GeP}_{2} \mathrm{~S}_{12}$. J. Am. Ceram. Soc. 98, 3352-3360. doi:10.1111/ jace. 13694

Ito, S., Nakakita, M., Aihara, Y., Uehara, T., and Machida, N. (2014). A synthesis of crystalline $\mathrm{Li}_{7} \mathrm{P}_{3} \mathrm{~S}_{11}$ solid electrolyte from 1, 2-dimethoxyethane solvent. J. Power Sources 271, 342-345. doi:10.1016/j.jpowsour.2014.08.024

Jansen, M., and Henseler, U. (1992). Synthesis, structure determination, and ionic conductivity of sodium tetrathiophosphate. J. Solid State Chem. 99, 110-119. doi:10.1016/0022-4596(92)90295-7

Ji, X., and Nazar, L. (2010). Advances in Li-S batteries. J. Mater. Chem. 20, 9821-9826. doi:10.1039/b925751a

Kamaya, N., Homma, K., Yamakawa, Y., Hirayama, M., Kanno, R., Yonemura, M., et al. (2011). A lithium superionic conductor. Nat. Mater 10, 682-686. doi:10.1038/nmat3066

Kato, A., Hayashi, A., and Tatsumisago, M. (2016a). Enhancing utilization of lithium metal electrodes in all-solid-state batteries by interface modification with gold thin films. J. Power Sources 309, 27-32. doi:10.1016/j.jpowsour. 2016.01.068
Kato, Y., Hori, S., Saito, T., Suzuki, K., Hirayama, M., Mitsui, A., et al. (2016b). High-power all-solid-state batteries using sulfide superionic conductors. Nat. Energy 1, 16030. doi:10.1038/nenergy.2016.30

Liu, Z., Fu, W., Payzant, E., Yu, X., Wu, Z., Dudney, N., et al. (2013). Anomalous high ionic conductivity of nanoporous $\beta$ - $\mathrm{Li}_{3} \mathrm{PS}_{4}$. J. Am. Chem. Soc. 135, 975-978. doi:10.1021/ja3110895

Mai, L. Q., Minhas-Khan, A., Tian, X., Hercule, K. M., Zhao, Y. L., Lin, X., et al. (2013). Synergistic interaction between redox-active electrolyte and binder-free functionalized carbon for ultrahigh supercapacitor performance. Nat. Commun. 4, 2923. doi:10.1038/ncomms 3923

Matsuyama, T., Deguchi, M., Mitsuhara, K., Ohta, T., Mori, T., Orikasa, Y., et al. (2016a). Structure analyses using X-ray photoelectron spectroscopy and X-ray absorption near edge structure for amorphous $\mathrm{MS}_{3}(\mathrm{M}: \mathrm{Ti}, \mathrm{Mo})$ electrodes in all-solid-state lithium batteries. J. Power Sources 313, 104-111. doi:10.1016/j.jpowsour.2016. 02.044

Matsuyama, T., Hayashi, A., Ozaki, T., Mori, S., and Tatsumisago, M. (2016b). Improved electrochemical performance of amorphous $\mathrm{TiS}_{3}$ electrodes compared to its crystal for all-solid-state rechargeable lithium batteries. J. Ceram. Soc. Jpn. 124, 242-246. doi:10.2109/jcersj2.15299

Minami, K., Hayashi, A., and Tatsumisago, M. (2010). Characterization of solid electrolytes prepared from $\mathrm{Li}_{2} \mathrm{~S}-\mathrm{P}_{2} \mathrm{~S}_{5}$ glass and ionic liquids. J. Electrochem. Soc. 157, A1296-A1301. doi:10.1149/1.3489352

Minami, K., Hayashi, A., Ujiie, S., and Tatsumisago, M. (2011). Electrical and electrochemical properties of glass-ceramic electrolytes in the systems $\mathrm{Li}_{2} \mathrm{~S}_{-} \mathrm{P}_{2} \mathrm{~S}_{5}-\mathrm{P}_{2} \mathrm{~S}_{3}$ and $\mathrm{Li}_{2} \mathrm{~S}-\mathrm{P}_{2} \mathrm{~S}_{5}-\mathrm{P}_{2} \mathrm{O}_{5}$. Solid State Ionics. 192, 122-125. doi:10.1016/j.ssi.2010.06.018

Mizuno, F., Hayashi, A., Tadanaga, K., and Tatsumisago, M. (2005). New, highly ion-conductive crystals precipitated from $\mathrm{Li}_{2} \mathrm{~S}_{-} \mathrm{P}_{2} \mathrm{~S}_{5}$ glasses. Adv. Mater. 17, 918-921. doi:10.1002/adma.200401286

Mizuno, F., Hayashi, A., Tadanaga, K., and Tatsumisago, M. (2006). High lithium ion conducting glass-ceramics in the system $\mathrm{Li}_{2} \mathrm{~S}-\mathrm{P}_{2} \mathrm{~S}_{5}$. Solid State Ionics. 177, 2721-2725. doi:10.1016/j.ssi.2006.04.017

Muramatsu, H., Hayashi, A., Ohtomo, T., Hama, S., and Tatsumisago, M. (2011). Structural change of $\mathrm{Li}_{2} \mathrm{~S}-\mathrm{P}_{2} \mathrm{~S}_{5}$ sulfide solid electrolytes in the atmosphere. Solid State Ionics. 182, 116-119. doi:10.1016/j.ssi.2010.10.013

Nagao, M., Hayashi, A., and Tatsumisago, M. (2011). Sulfur-carbon composite electrode for all-solid-state $\mathrm{Li} / \mathrm{S}$ battery with $\mathrm{Li}_{2} \mathrm{~S}_{-} \mathrm{P}_{2} \mathrm{~S}_{5}$ solid electrolyte. Electrochim. Acta 56, 6055-6059. doi:10.1016/j.electacta.2011.04.084

Nagao, M., Hayashi, A., and Tatsumisago, M. (2012a). Bulk-type lithium metal secondary battery with indium thin layer at interface between $\mathrm{Li}$ electrode and $\mathrm{Li}_{2} \mathrm{~S}-\mathrm{P}_{2} \mathrm{~S}_{5}$ solid electrolyte. Electrochem. 80, 734-736. doi:10.5796/ electrochemistry.80.734

Nagao, M., Hayashi, A., and Tatsumisago, M. (2012b). High-capacity Li 2 Snanocarbon composite electrode for all-solid-state rechargeable lithium batteries. J. Mater. Chem 22, 10015-10020. doi:10.1039/c2jm16802b

Nagao, M., Hayashi, A., Tatsumisago, M., Ichinose, T., Ozaki, T., Togawa, Y., et al. (2015). $\mathrm{Li}_{2} \mathrm{~S}$ nanocomposites underlying high-capacity and cycling stability in all-solid-state lithium-sulfur batteries. J. Power Sources 274, 471-476. doi:10.1016/j.jpowsour.2014.10.043

Nagao, M., Hayashi, A., Tatsumisago, M., Kanetsuku, T., Tsuda, T., and Kuwabata, S. (2013). In situ SEM study of a lithium deposition and dissolution mechanism in a bulk-type solid-state cell with a $\mathrm{Li}_{2} \mathrm{~S}-\mathrm{P}_{2} \mathrm{~S}_{5}$ solid electrolyte. Phys. Chem. Chem. Phys. 15, 18600-18606. doi:10.1039/c3cp51059j

Nose, M., Kato, A., Sakuda, A., Hayashi, A., and Tatsumisago, M. (2015). Evaluation of mechanical properties of $\mathrm{Na}_{2} \mathrm{~S}-\mathrm{P}_{2} \mathrm{~S}_{5}$ sulfide glass electrolytes. J. Mater. Chem. A 3, 22061-22065. doi:10.1039/C5TA05590C

Oh, D. Y., Nam, Y. J., Park, K. H., Jung, S. H., Cho, S. J., Kim, Y. K., et al. (2015). Excellent compatibility of solvate ionic liquids with sulfide solid electrolytes: toward favorable ionic contacts in bulk-type all-solid-state lithium-ion batteries. Adv. Energy Mater. 5, 1500865. doi:10.1002/aenm.201570120

Ohtomo, T., Hayashi, A., Tatsumisago, M., and Kawamoto, K. (2013a). Glass electrolytes with high ion conductivity and high chemical stability in the system $\mathrm{LiI}_{-} \mathrm{Li}_{2} \mathrm{O}-\mathrm{Li}_{2} \mathrm{~S}-\mathrm{P}_{2} \mathrm{~S}_{5}$. Electrochemistry 81, 428-431. doi:10.5796/ electrochemistry.81.428

Ohtomo, T., Hayashi, A., Tatsumisago, M., and Kawamoto, K. (2013b). Allsolid-state batteries with $\mathrm{Li}_{2} \mathrm{O}-\mathrm{Li}_{2} \mathrm{~S}-\mathrm{P}_{2} \mathrm{~S}_{5}$ glass electrolytes synthesized by two-step mechanical milling. J. Solid State Chem. 17, 2551-2557. doi:10.1007/ s10008-013-2149-5

Ohtomo, T., Hayashi, A., Tatsumisago, M., and Kawamoto, K. (2013c). Allsolid-state lithium secondary batteries using the $75 \mathrm{Li}_{2} \mathrm{~S} \cdot 25 \mathrm{P}_{2} \mathrm{~S}_{5}$ glass and the 
$70 \mathrm{Li}_{2} \mathrm{~S} \cdot 30 \mathrm{P}_{2} \mathrm{~S}_{5}$ glass-ceramic as solid electrolytes. J. Power Sources 233, 231-235. doi:10.1016/j.jpowsour.2013.01.090

Okita, K., Ikeda, K., Sano, H., Iriyama, Y., and Sakaebe, H. (2011). Stabilizing lithium plating-stripping reaction between a lithium phosphorus oxynitride glass electrolyte and copper thin film by platinum insertion. J. Power Sources 196, 2135-2142. doi:10.1016/j.jpowsour.2010.10.014

Phuc, N., Morikawa, K., Totani, M., Muto, H., and Matsuda, A. (2016). Chemical synthesis of $\mathrm{Li}_{3} \mathrm{PS}_{4}$ precursor suspension by liquid-phase shaking. Solid State Ionics. 285, 2-5. doi:10.1016/j.ssi.2015.11.019

Sahu, G., Lin, Z., Li, J., Liu, Z., Dudney, N., and Liang, C. (2014). Air-stable, high-conduction solid electrolytes of arsenic-substituted $\mathrm{Li}_{4} \mathrm{SnS}_{4}$. Energy Environ. Sci. 7, 1053-1058. doi:10.1039/C3EE43357A

Sakuda, A., Hayashi, A., Ohtomo, T., Hama, S., and Tatsumisago, M. (2010). $\mathrm{LiCOO}_{2}$ electrode particles coated with $\mathrm{Li}_{2} \mathrm{~S}-\mathrm{P}_{2} \mathrm{~S}_{5}$ solid electrolyte for all-solid-state batteries. Electrochem. Solid-State Lett. 13, A73-A75. doi:10.1149/1.3376620

Sakuda, A., Hayashi, A., Ohtomo, T., Hama, S., and Tatsumisago, M. (2011). All-solid-state lithium secondary batteries using $\mathrm{LiCoO}_{2}$ particles with pulsed laser deposition coatings of $\mathrm{Li}_{2} \mathrm{~S}_{-} \mathrm{P}_{2} \mathrm{~S}_{5}$ solid electrolytes. J. Power Sources 196, 6735-6741. doi:10.1016/j.jpowsour.2010.10.103

Sakuda, A., Hayashi, A., Takigawa, Y., Higashi, K., and Tatsumisago, M. (2013a). Evaluation of elastic modulus of $\mathrm{Li}_{2} \mathrm{~S}-\mathrm{P}_{2} \mathrm{~S}_{5}$ glassy solid electrolyte by ultrasonic sound velocity measurement and compression test. J. Ceram. Soc. Jpn. 121, 946-949. doi:10.2109/jcersj2.121.946

Sakuda, A., Hayashi, A., and Tatsumisago, M. (2013b). Sulfide solid electrolyte with favorable mechanical property for all-solid-state lithium battery. Sci. Rep. 3, 2261. doi:10.1038/srep02261

Sakuda, A., Taguchi, N., Takeuchi, T., Kobayashi, H., Sakaebe, H., Tatsumi, K., et al. (2014). Amorphous niobium sulfides as novel positive-electrode materials. ECS Electrochem. Lett. 3, A79-A81. doi:10.1149/2.0091407eel

Seino, Y., Ota, T., Takada, K., Hayashi, A., and Tatsumisago, M. (2014). A sulphide lithium super ion conductor is superior to liquid ion conductors for use in rechargeable batteries. Energy Environ. Sci. 7, 627-631. doi:10.1039/ C3EE41655K

Souquet, J. L., Robinel, E., Barrau, B., and Ribes, M. (1981). Glass formation and ionic conduction in the $\mathrm{M}_{2} \mathrm{~S}-\mathrm{GeS}_{2}(\mathrm{M}=\mathrm{Li}, \mathrm{Na}, \mathrm{Ag})$ systems. Solid State Ionics. 3-4, 317-321. doi:10.1016/0167-2738(81)90105-3

Takada, K. (2013). Progress and prospective of solid-state lithium batteries. Acta Mater. 61, 759-770. doi:10.1016/j.actamat.2012.10.034

Tanibata, N., Hayashi, A., and Tatsumisago, M. (2015a). Improvement of rate performance for all-solid-state $\mathrm{Na}_{15} \mathrm{Sn}_{4} /$ amorphous $\mathrm{TiS}_{3}$ cells using $94 \mathrm{Na}_{3} \mathrm{PS}_{4} \cdot 6 \mathrm{Na}_{4} \mathrm{SiS}_{4}$ glass-ceramic electrolytes. J. Electrochem. Soc. 162, A793-A795. doi:10.1149/2.0011506jes

Tanibata, N., Matsuyama, T., Hayashi, A., and Tatsumisago, M. (2015b). Improvement of rate performance for all-solid-state $\mathrm{Na}_{15} \mathrm{Sn}_{4} /$ amorphous $\mathrm{TiS}_{3}$ cells using $94 \mathrm{Na}_{3} \mathrm{PS}_{4} \cdot 6 \mathrm{Na}_{4} \mathrm{SiS}_{4}$ glass-ceramic electrolytes. J. Power Sources 275 , 284-287. doi:10.1016/j.jpowsour.2014.10.193

Tanibata, N., Noi, K., Hayashi, A., Kitamura, N., Idemoto, Y., and Tatsumisago, M. (2014). X-ray crystal structure analysis of sodium-ion conductivity in $94 \mathrm{Na}_{3} \mathrm{PS}_{4} \cdot 6 \mathrm{Na}_{4} \mathrm{SiS}_{4}$ glass-ceramic electrolytes. Chem. Electro. Chem. 1 , 1130-1132. doi:10.1002/celc.201402016

Tatsumisago, M., and Hayashi, A. (2008). All-solid-state lithium secondary batteries using sulfide-based glass-ceramic electrolytes. Funct. Mater. Lett. 1, 31-36. doi:10.1142/S1793604708000071

Tatsumisago, M., and Hayashi, A. (2014). Sulfide glass-ceramic electrolytes for all-solid-state lithium and sodium batteries. Int. J. Appl. Glass. Sci. 5, 226-235. doi:10.1111/ijag. 12084
Tatsumisago, M., Nagao, M., and Hayashi, A. (2013). Recent development of sulfide solid electrolytes and interfacial modification for all-solid-state rechargeable lithium batteries. J. Asian. Ceram. Soc. 1, 17-25. doi:10.1016/j.jascer.2013. 03.005

Tatsumisago, M., Shinkuma, Y., and Minami, T. (1991). Stabilization of superionic $\alpha$ - $\mathrm{AgI}$ at room temperature in a glass matrix. Nature $354,217-218$. doi:10.1038/354217a0

Teragawa, S., Aso, K., Tadanaga, K., Hayashi, A., and Tatsumisago, M. (2014a). Liquid-phase synthesis of a $\mathrm{Li}_{3} \mathrm{PS}_{4}$ solid electrolyte using $\mathrm{N}$-methylformamide for all-solid-state lithium batteries. J. Mater. Chem. A 2, 5095-5099. doi:10.1039/ c3ta15090a

Teragawa, S., Aso, K., Tadanaga, K., Hayashi, A., and Tatsumisago, M. (2014b). Preparation of $\mathrm{Li}_{2} \mathrm{~S}-\mathrm{P}_{2} \mathrm{~S}_{5}$ solid electrolyte from $\mathrm{N}$-methylformamide solution and application for all-solid-state lithium battery. J. Power Sources 248, 939-942. doi:10.1016/j.jpowsour.2013.09.117

Ujiie, S., Hayashi, A., and Tatsumisago, M. (2014). Preparation and electrochemical characterization of $(100-\mathrm{x})\left(0.7 \mathrm{Li}_{2} \mathrm{~S} \cdot 0.3 \mathrm{P}_{2} \mathrm{~S}_{5}\right) \cdot \mathrm{xLiBr}$ glass-ceramic electrolytes. Mater. Renew. Sustain. Energy 3, 1-8. doi:10.1007/s40243-013-0018-x

Wada, H., Menetrier, M., Levasseur, A., and Hagenmuller, P. (1983). Preparation and ionic conductivity of new $\mathrm{B}_{2} \mathrm{~S}_{3}-\mathrm{Li}{ }_{2} \mathrm{~S}-\mathrm{LiI}$ glasses. Mater. Res. Bull. 18, 189-193. doi:10.1016/0025-5408(83)90080-6

Yabuchi, N., Kubota, K., Dahbi, M., and Komaba, S. (2015b). Research development on sodium-ion batteries. Chem. Rev. 114, 11636-11682. doi:10.1021/ cr500192f

Yamada, A. (2014). Iron-based materials strategies. MRS Bull. 39, 423-428. doi:10.1557/mrs.2014.89

Yamauchi, A., Sakuda, A., Hayashi, A., and Tatsumisago, M. (2013). Preparation and ionic conductivities of $(100-\mathrm{x})\left(0.75 \mathrm{Li}_{2} \mathrm{~S} \cdot 0.25 \mathrm{P}_{2} \mathrm{~S}_{5}\right) \cdot \mathrm{xLiBH}_{4}$ glass electrolytes. J. Power Sources 244, 707-710. doi:10.1016/j.jpowsour.2012.12.001

Yubuchi, S., Hayashi, A., and Tatsumisago, M. (2015a). Sodium-ion conducting $\mathrm{Na}_{3} \mathrm{PS}_{4}$ electrolyte synthesized via a liquid-phase process using $\mathrm{N}$-methylformamide. Chem. Lett. 44, 884-886. doi:10.1246/cl.150195

Yubuchi, S., Teragawa, S., Aso, K., Tadanaga, K., Hayashi, A., and Tatsumisago, M. (2015b). Preparation of high lithium-ion conducting $\mathrm{Li}_{6} \mathrm{PS}_{5} \mathrm{Cl}$ solid electrolyte from ethanol solution for all-solid-state lithium batteries. J. Power Sources 293, 941-945. doi:10.1016/j.jpowsour.2015.05.093

Zhang, L., Yang, K., Mi, J., Lu, L., Zhao, L., Wang, L., et al. (2015). Solid electrolytes: $\mathrm{Na}_{3} \mathrm{PSe}_{4}$ : a novel chalcogenide solid electrolyte with high ionic conductivity. Adv. Energy Mater 5, 1501294. doi:10.1002/aenm.201501294

Zhang, Z., and Kennedy, J. H. (1990). Synthesis and characterization of the $\mathrm{B}_{2} \mathrm{~S}_{3^{-}}$ $\mathrm{Li}_{2} \mathrm{~S}$, the $\mathrm{P}_{2} \mathrm{~S}_{5}-\mathrm{Li}_{2} \mathrm{~S}$ and the $\mathrm{B}_{2} \mathrm{~S}_{3}-\mathrm{P}_{2} \mathrm{~S}_{5}-\mathrm{Li}_{2} \mathrm{~S}$ glass systems. Solid State Ionics. 38, 217-224. doi:10.1016/0167-2738(90)90424-P

Zhu, Z., Chu, I.-H., Deng, Z., and Ong, S. P. (2015). Role of $\mathrm{Na}^{+}$interstitials and dopauts in enhancing the $\mathrm{Na}^{+}$conductivity of the cubic $\mathrm{Na}_{3} \mathrm{PS}_{4}$ superionic conductor. Chem. Mater. 27, 8318-8325. doi:10.1021/acs.chemmater. $5 \mathrm{~b} 03656$

Conflict of Interest Statement: The authors declare that the research was conducted in the absence of any commercial or financial relationships that could be construed as a potential conflict of interest.

Copyright $\odot 2016$ Hayashi, Sakuda and Tatsumisago. This is an open-access article distributed under the terms of the Creative Commons Attribution License (CC BY). The use, distribution or reproduction in other forums is permitted, provided the original author(s) or licensor are credited and that the original publication in this journal is cited, in accordance with accepted academic practice. No use, distribution or reproduction is permitted which does not comply with these terms. 